\title{
INVESTMENT TIES GONE AWRY
}

\author{
KOUROSH SHAFI \\ California State University, East Bay \\ ALI MOHAMMADI \\ Copenhagen Business School \\ SOFIA A. JOHAN \\ Florida Atlantic University
}

Forming early relationships increases entrepreneurial ventures' chances of survival and success by allowing access to critical resources from partners. However, since not all ventures achieve their desired goals through collaboration due to uncertainty, such relationships are sometimes abandoned. This paper investigates the costs of ties that have gone awry in the context of venture capital investments. We conjecture that the adverse perceptions of signals associated with tie discontinuation reduce an investee venture's valuation in the follow-on round of financing by partially deterring prospective investors, particularly higher-quality ones, from joining the syndicate. By examining large-sample evidence that supports our theory, we suggest that early entrepreneurial ties to venture capitalists may be a double-edged sword, especially in light of the costs of the discontinuation.

Keywords: Inter-organizational relationships, reputation, signaling theory, tie discontinuation, venture capital 


\section{INTRODUCTION}

Chris Dixon, a general partner at top-tier venture capital (VC) firm Andreessen Horowitz said: "This investor signaling has a huge effect on venture financing dynamics. If Sequoia wants to invest, so will every other investor. If Sequoia gave you seed money before but now doesn't want to follow on, you're probably dead." ${ }^{\text {11 }}$ Voicing similar concerns, Jon Sakoda, co-manager of the seed program at New Enterprise Associates — one of the largest and most active VC firms globally — recalled, "we had talked to lots of entrepreneurs or other seed investors about whether or not our participation in the next rounds would actually undermine our relationships with entrepreneurs." ${ }^{\prime 2}$ A scenario that involves the non-repetition of ties with venture investors elucidates a source of tension for entrepreneurial ventures: what are the downsides of forming early relationships when investors discontinue their investments? With limited resource endowments, entrepreneurial ventures may have little choice but to turn to investors, but lacking status and power, they have little control over their investors' actions (Pahnke, Katila, $\&$ Eisenhardt, 2015) and other prospective investors' adverse perceptions of such actions ${ }^{3}$

Research to date considers early relationships as an opportunity for entrepreneurial ventures to grow, develop, and overcome the "liability of newness" (Stinchcombe, 1965). Early relationships provide entrepreneurs with critical resources from prospective partners and investors, along with access to advantageous social positions (Alvarez-Garrido \& Dushnitsky,

\footnotetext{
${ }^{1}$ http://cdixon.org/2010/03/12/the-importance-of-investor-signaling-in-venture-pricing/

2 https://techcrunch.com/2013/07/12/ask-a-vc-neas-jon-sakoda-on-why-the-venture-firm-makes-seedinvestments-and-more/

3 "If you sometimes follow-on and sometimes don't, then not following-on is a signal to the new investors that they're making a mistake (signaling again.)" wrote Jerry Neumann from NeuVC (http://reactionwheel.net/2017/06/venture-follow-on-and-the-kelly-criterion.html). Additionally, Y Combinator (a prominent accelerator) launched a growth fund and emphasized in their strategy that they would not invest in the early stage investments of their own ventures (https://techcrunch.com/2015/10/15/former-twitter-coo-alirogwhani-to-lead-y-combinators-growth-fund/ ); When asked about signaling risk and whether Y Combinator could doom its portfolio ventures if it does not back them as they mature, Rowghani shrugged off the concern: "We're staying away from early stage precisely because we want to avoid [the] signaling issue, which is most acute when companies are just departing from [the accelerator program of] Y Combinator, when we have more information about them than most investors."
} 
2015; Katila, Rosenberger, \& Eisenhardt, 2008). However, this perspective ignores the reality that young ventures might not achieve their desired goalsthrough collaborations; thus, these collaborations are discontinued (organizations that are more established also frequently dissolve their ties, see Kale \& Singh, 2009). During the period from 1985 to 2007, about 24\% of the entrepreneurial ventures we studied lost at least one investor collaboration. This is rather surprising, since both anecdotal evidence and empirical research have suggested that investors are expected to participate in follow-on financing in order to benefit from financial returns, especially in the case of positive outcomes. Early relationships can be sub-optimal mismatches, as they are subject to the extensive uncertainty and unpredictability that surround the development of young ventures. Therefore, given the difficulty that entrepreneurs have in identifying partners with the kinds of resources and expertise that would increase their chances of success, and taking into consideration the somewhat prevalent discontinuation of investment relationships, it becomes critical to investigate the performance cost to the venture resulting from the non-repetition of collaborative ties (hereafter, VC withdrawal). ${ }^{4}$

For ventures lacking a repetition of ties by one of their existing VC investors, this study examines the financial outcomes (i.e., their valuation at the time at which the capital is raised and the amount of capital raised) and the underlying mediating factors related to the venture's likelihood of attracting new investors (especially those possessing desirable attributes, such as status and reputation). Two plausible theoretical mechanisms link how a VC firm's decision not to reinvest in a focal new funding round affects the portfolio venture's (hereafter, venture) prospects in that focal funding round. The first trivial mechanism is that the VC firm becomes privy to private, insider information on the venture's poor prospects, and hence the withdrawal decision is a negative signal of venture quality, which is eventually revealed in the venture's

\footnotetext{
${ }^{4}$ In this study, we use the terms 'withdrawal' and 'non-repetition of ties' interchangeably. Note that when a VC firm stops investing in subsequent rounds, it can retain its (diluted) equity in the venture or sell its equity in the secondary market. In the latter case, the VC firm fully terminates its relationship with the venture (i.e., tie dissolution). We will address the implications of this distinction for our results in the discussion section.
} 
adverse financials in that focal funding round. We call this the "private information" mechanism.

The second mechanism is that the withdrawal adversely influences the perceptions of new potential VC firms about focal venture's quality (perceived quality), regardless of its underlying true quality (which is difficult to observe directly). Potential new investors, making decisions under uncertainty and information asymmetry, face an adverse selection issue because they are unsure of the focal venture's quality - since what they observe is the withdrawal by the currently invested VC firm, they can potentially interpret that as a negative signal. We call this the "adverse selection" mechanism.

At the extreme, if an insider chooses not to participate in the follow-on round for reasons unrelated to the venture's underlying value and prospects of success, it could lead a perfectly viable venture to experience a negative fundraising performance. For example, corporate VC firms may shift their focus to other opportunities on an ad hoc basis (Dushnitsky, 2012; Gaba \& Meyer, 2008), which may disrupt their follow-on investment in a particular venture. Therefore, it becomes difficult for other potential investors to determine whether such a withdrawal was due to changing corporate priorities or if the corporate $\mathrm{VC}$ firm possessed certain information that caused it to discontinue its investment. Therefore, withdrawing VC exposes the venture and the rest of the syndicate to "adverse selection" consequences, even if the venture continues to progress well.

To distinguish these two confounding mechanisms, in our econometric analysis we assume that "private information" about the prospects of the venture is an omitted variable (i.e., unobservable). The omitted variable linked to "private information" can bias the "adverse selection" consequences of withdrawal on a venture's valuation unless appropriate econometric methods are used to address potential endogeneity concerns arising from omitted variable bias. A common approach to this problem is Heckman's two-stage treatment specification (Li \& 
Prabhala, 2007). This approach allows the impact of VC withdrawal on the venture's valuation not to be biased by the confounding effect of "private information" on the underlying, yet unobservable, quality of the venture. Furthermore, "adverse selection" concerns are especially important under conditions of uncertainty: the greater the uncertainty (for example, during the early stages of venture development) about the quality of the venture, the greater the negative impact of the withdrawal on the venture's valuation in the focal round of funding. ${ }^{5}$ We also investigate how increased adverse selection concerns from VC withdrawal deter new prospective investors (especially those that with high-status and high-reputation qualities) and how this lack of interest from new prospective investors mediates the negative relationship between VC withdrawal and a venture's valuation. To test our hypotheses, we use VC investment data from the Thomson SDC Platinum database over a span of 22 years.

This paper offers two contributions. First, we extend the understanding of how relationships (or a lack thereof) can affect young ventures. Prior research has mostly considered the benefits of early relationships and offered a consensus on the positive outcomes for ventures that have secured venture investment (Gompers \& Lerner, 1999; Hsu, 2006; Puri \& Zarutskie, 2012). In contrast, we add to the limited but growing body of work that underscores the potential downsides (from the entrepreneur's perspective) associated with investment relationships. These include taking a company public prematurely as a means of grandstanding (Gompers, 1996), leaking sensitive information to other portfolio ventures (Pahnke et al., 2015), or exposing valuable technologies to competitors (Colombo \& Shafi, 2016; Diestre \& Rajagopalan, 2012; Dushnitsky \& Shaver, 2009; Katila et al., 2008). In contrast to the ex-ante

\footnotetext{
${ }^{5}$ We have performed a series of additional tests that reinforce our confidence in the adverse selection mechanism. First, we construct a "treatment" group where each venture with withdrawal is paired with one "control" venture based on similar observable characteristics. The matching attempts to mimic randomization by creating a sample of ventures that received the treatment that is comparable on all observed characteristics to a sample of ventures that did not receive the treatment. We find similar results using matching methods. Second, we report similar findings in the sample of ventures with successful exits, acting as a proxy for high-quality ventures at the time of withdrawal (i.e., low probability of negative private information).
} 
considerations for tie formation, the ex-post consequences of the non-repetition of ties are the focus of this work, especially when these decisions are made at the discretion of a high-powered exchange party. By documenting several negative consequences of $\mathrm{VC}$ withdrawal for entrepreneurial ventures, we add to the existing work that has explored the link between the negative consequences of financial liquidity shocks on $\mathrm{VC}$ investors and the fundraising ability of new ventures (Townsend, 2015).

Our second contribution is to integrate more closely the literature on partner selection (who forms ties with whom) (Chung, Singh, \& Lee, 2000; Gulati, 1995; Sorenson \& Stuart, 2008) and signaling theory (Connelly, Certo, Ireland, \& Reutzel, 2011). While the conversation on signaling opportunities for young ventures imbued with extant information asymmetry has grown to become an important theoretical contribution to understanding the various outcomes, including valuations or materializing valuable ties with partners (Gulati \& Higgins, 2003; Megginson \& Weiss, 1991; Ozmel, Reuer, \& Gulati, 2013; Reuer, Tong, \& Wu, 2012; Sanders \& Boivie, 2004; Stuart, Hoang, \& Hybels, 1999), this theoretical framework has been less engaged in explaining the quality of the selected partners and how this heterogeneity can mediate the effect of signals on valuations. Therefore, we specifically focus on whether signals facilitate access to exchange partners that have valuable intangible assets, such as organizational reputation and status (Washington \& Zajac, 2005). In doing so, we extend prior work on signaling that only tends to control for the heterogeneity of partners instead of embracing it as an important mediating factor (Pollock \& Gulati, 2007; Stern, Dukerich, \& Zajac, 2014).

\section{THEORY AND HYPOTHESES}

In an attempt to depart from prior research on the benefits of relationships for young ventures, researchers have recently explored the potential negative consequences of forming some ties over others (Diestre \& Rajagopalan, 2012; Dushnitsky \& Shaver, 2009; Pahnke, McDonald, 
Wang, \& Hallen, 2015). In focusing on the negative consequences of the ties formed, this line of work overlooked the frequently observed issue of discontinued ties and their consequences. Moreover, only a small body of research has considered tie dissolutions (Ahuja, Polidoro, \& Mitchell, 2009; Greve, Baum, Mitsuhashi, \& Rowley, 2010; Greve, Mitsuhashi, \& Baum, 2013). Our perspective here differs from previous work, as we consider the performance consequences of tie discontinuations in the context of young entrepreneurial ventures.

What motivates entrepreneurial ventures to seek investment ties with intermediaries? Entrepreneurial ventures typically begin with limited resource endowments and seek partners to obtain resources such as capital, complementary assets, contacts, and advice. Extant research has documented the myriad positive effects of such ties on venture performance, ranging from innovation (Kortum \& Lerner, 2000) to growth and the likelihood of going public (Chemmanur et al., 2010; Cumming \& Johan, 2013; Puri \& Zarutskie, 2012). However, the entrepreneur's weaker position in an investment relationship gives them little control over their partner's subsequent decisions (Garg, 2013). This is so because investors typically ask for control rights; even though they are not major shareholders, they ask for board rights in order to take control of the venture should problems arise. In addition, VCs can also non-contractually control the venture's fate. Even though VCs invest in stages to elicit more effort from entrepreneurs (to address moral hazard problems), they have the discretion to discontinue. The following discussion expands on a few antecedents of tie discontinuations.

The decision to withdraw financial support may be related to a venture's underperformance. A VC learns more about the venture over time through monitoring (Sahlman, 1990). When the venture underperforms, or fails to achieve the milestones that are set a priori, the VC might update its expectations about the venture's prospects downwards (Gompers, 1995). Accordingly, the withdrawal should reflect the negative "private information" learned after investment, suggesting a revised assessment of lower success 
probability. Note that the VC's evaluation of future success is arguably subjective and made under uncertainty, as evidenced by the highly skewed returns of VC investors (Cochrane, 2005; Kaplan \& Schoar, 2005).

The VC's decision to withdraw from an investment may be unrelated to the venture's performance but related to a host of other factors, especially when other syndicate members choose to recommit their resources in the focal new funding round. One reason for withdrawal may be financial constraints. After the collapse of the technology bubble, investors with greater Internet exposure (who presumably faced more liquidity pressures) were less likely to continue to participate in follow-on rounds of non-Internet companies (Townsend, 2015). VCs may face contractual prohibitions from investing further from the same fund in the venture's follow-on round (e.g., when VCs have contractual agreements with their limited partners only to invest in seed or early-stage ventures and their focal investee venture has reached the growth or expansion stage). Moreover, they are often contractually prohibited from using other funds under their management because limited partners perceive such cross-fund investment as a moral hazard problem.

Besides the limited fund size, uncertainties regarding technological development and market adoption trajectories can result in miscalculations about timing decisions by VCs that are under pressure from limited partners that demand (liquid) returns, typically around seven to ten years after the fundraising (Cumming \& Johan, 2013). Furthermore, conflicts of interest among investors might lead to the withdrawal of VCs, and VCs may pursue different goals depending on their organizational affiliation. For instance, corporate VCs pursue strategic objectives rather than financial returns alone (Dushnitsky, 2012). Principal-principal agency conflicts also ensue from the goal incongruence between the independent VCs and VCs affiliated with banks, corporations, or governments (Chahine, Arthurs, Filatotchev, \& Hoskisson, 2012). Finally, increased investment opportunities in nearby geographical markets 
(outside options) may induce VCs to redeploy their resources to alternative ventures that offer informational advantages, such as lower monitoring costs (Bernstein, Giroud, \& Townsend, 2016). Taken together, a VC's decision to withdraw may not necessarily relate to the negative private information on the quality of the venture learned after investment, but rather relate to issues such as those summarized above.

\section{Venture Valuation}

Given the uncertainties surrounding the survival chances and financial prospects of new ventures, VCs face decision-making challenges in their investment process that involve deal sourcing, investment selection, valuation, deal structure, post-investment value added, and exits. While researchers have studied some aspects of this process extensively (for reviews, see Gompers \& Lerner, 2001; Da Rin, Hellmann, \& Puri, 2011), we overview the few studies on valuations of privately held ventures. This area of research is relevant to both venture capitalists and entrepreneurs, and despite marked differences with valuations of publicly traded ventures, it has received less academic attention (Claes \& Vissa, 2017).

The valuation of VC-funded and privately held ventures differs from the valuation of publicly traded ventures (the latter has amassed a large body of theory and evidence, such as the capital asset pricing model). First, the typical targets of venture capital investments are new ventures with limited track records and long horizons towards product development and commercialization. As a result, historical performance data is unavailable or unreliable to use, as in the case of the public market. Second, unlike the passive role held by many investors in public ventures, venture investments usually require direct involvement and monitoring that can be priced in the valuations (Hsu, 2004). Third, VC investments are illiquid assets, meaning that in the short-term, exchange markets for equity shares of privately held ventures are inefficient (or lacking) and liquidity events may take many years to take place. Therefore, in the absence of an efficient pricing mechanism, the venture valuation is informed by investors' 
subjective assessment procedures and is to some extent negotiated based on the relative bargaining power of VCs and entrepreneurs (Tyebjee \& Bruno, 1984).

Previous studies that have investigated venture valuation highlight the role of business cycles, VC firm characteristics, the industry in which the venture operates, and ultimately the quality of the venture's resources. Valuations increase in line with inflows of capital into venture funds (Gompers \& Lerner, 2000), typically coinciding with favorable valuations in public markets (Gompers, Kovner, Lerner, \& Scharfstein, 2008) and reduced barriers to entry for new VC firms in a local market (Hochberg, Ljungqvist, \& Lu, 2010). Focusing on VC firm characteristics, Hsu (2004) notes that high-reputation VCs acquire venture equity at a 10-14\% discount because of the bundle of services and certifications these investors provide to their portfolio ventures. Ge et al. (2005) show that industry-relevant factors, including growth in demand and research and development intensity, correlate with valuations of ventures operating in that particular industry. Finally, valuations correlate with venture quality. Valuations are higher when ventures possess better resource endowments, such as organizational human capital in terms of (successful) founding experience, education and experience of the management team (Ge et al., 2005; Hsu, 2007), and superior technological and marketing capabilities (Hsu and Ziedonis, 2013; Block et al., 2013. This category of information influences perceptions of the probability that a venture will succeed. Because the resource endowments of ventures are rarely sufficient to resolve the uncertainty about their underlying quality, investors also use another distinctive category of information on business relationships. Stuart et al. (1999) find that affiliations with prominent investment banks and strategic alliance partners influence the market value of biotechnology ventures at their initial public offering (IPO). The implicit transfer of status across inter-organizational exchange relations is the underlying reason for prospective collaborators' confidence in the quality of a new venture. 
In contrast to the sparse literature focusing on forming ties with (certain preferred) exchange partners and their implications for venture valuations, this paper considers the effect of discontinued business relationships on venture valuations. Investigating this link improves our 'insights into the mechanisms underlying business relationships that may influence venture valuations' (beyond those channels offered by prior studies on leasing the reputations of exchange parties). Syndication of investments with other investors characterizes the social structure of the VC industry. VC firms typically engage in syndication to share information and reduce the ex-ante risk associated with evaluating venture investments (Bygrave, 1987) (in addition to pooling resources and expertise for post-investment value adding). Given that seeking a "second opinion" is one of the rationales for syndication (Brander et al., 2002; Lerner, 1994), it will be especially valuable for prospective investors when that opinion is perceived to be informed and is expressed in the form of whether insider investors provide follow-on commitment of capital. Below we explicate how the non-repetition of investor ties alters prospective investors' perceptions of a venture's valuation.

\section{VC Withdrawal and Venture Valuation}

Entrepreneurial ventures present information asymmetry problems vis-à-vis prospective partners and investors, which are considered to be key impediments to obtaining access to resources from investors or collaborators. A limited track record and having only a few tangible assets in place raise adverse selection risks for prospective investors and decrease the likelihood of deal making. To alleviate problems associated with information asymmetry, prospective investors value signals that separate the wheat from the chaff, and entrepreneurs, in turn, use signals to shape potential investors' assessments of the latent potential of their ventures.

Prior research has shown how the valuation of ventures is influenced by signals of quality, such as a stock of technological assets as disclosed in the proven ability to patent (Hsu \& Ziedonis, 2013), teams with successful prior founding experience (Hsu, 2006), teams with 
prominent scientists (Higgins \& Gulati, 2006), VC backing, along with the amount of VC and the proportion of equity owned by VCs (Megginson \& Weiss, 1991; Sanders \& Boivie, 2004; Stuart et al., 1999), and prestigious executives in the top management team or prestigious outside directors on the venture's board (Certo, 2003; Pollock, Chen, Jackson, \& Hambrick, 2010). Overall, given that valuations at the early stage of ventures are negotiated rather than calculated (Hsu, 2004, 2007), prospective investors, faced with considerable uncertainty about the potential of the venture, appreciate the value of signals. These are broadly defined as the "activities or attributes of individuals in a market which by design or accident, alter the beliefs of, or convey information to, other individuals in the market" (Spence, 1974: 1). To this body of work, we add VC withdrawal from follow-on financing and highlight how it alters the perceptions of potential investors.

Two mechanisms link how VC withdrawal adversely affects the focal venture's valuation. The first mechanism is that $\mathrm{VC}$ withdrawal reflects negative private information learned by the investor and is thus a signal of a venture's poor prospects. A VC firm becomes privy to private, insider information on the venture's prospects through monitoring and often by sitting on the venture's board (Kaplan \& Stromberg, 2003). For example, the ability to observe first-hand the progress of the venture enables VCs to develop a sense of how good the team will be at executing the next stage of the venture's growth. If the VC's private information on the underlying value of the venture is negative (for example, if the venture's underlying project has not been making sufficient progress), then the insider VC may decide not to invest in the future rounds based on this new negative information. In this scenario, it is not surprising to find that a venture's lower (expected) performance decreases its valuation in the new focal funding round.

An alternative mechanism is that the withdrawal can indicate potential "adverse selection" problems for prospective investors who only observe the withdrawal but not the 
underlying quality of the venture directly or the potential reasons behind the withdrawal. VC withdrawal adversely influences the perceptions of prospective investors on the potential of the venture for the following reasons. First, the alignment of interests between insiders and new shareholders is reduced, potentially causing moral hazard problems (Leland \& Pyle, 1977). The continued financial commitment of investors (insiders/managers) is credible since insiders suffer a penalty if the venture does not perform well. Second, unlike withdrawing VCs with access to insider information, new potential investors do not have access to such information and can only observe insider VCs' actions. While new potential investors can gain access to some private information, such as audited financials, insiders nevertheless have access to privileged soft information that cannot be credibly communicated. Therefore, feeling uncertain about the nature of the private information or the underlying reason for the withdrawal, potential new VCs interpret it as a negative signal. Even if the underlying reason for withdrawal by the VCs was unrelated to the probability of success or the underlying value of the venture, the potential investors perceive the focal investment as high risk. Taken together, both these mechanisms suggest that $\mathrm{VC}$ withdrawal decreases the valuation of the venture in the followon round. ${ }^{6}$

Although it is tempting to believe that the magnitude of both positive and negative signals (from obtaining or losing affiliations) are the same, but in opposite directions (based on information economics), behavioral decision-making theory suggests that negative signals may be more salient than positive signals in shaping the perceptions of prospective investors. One of the basic tenets in behavioral decision-making theory is that the rationality of decisionmakers is bounded, rather than perfect (Cyert \& March, 1963; Simon, 1979). It is impossible for decision-makers to fully evaluate all information because this requires extensive cognitive

\footnotetext{
${ }^{6}$ In our econometric analysis, we manage to distinguish between these two mechanisms and show results that support the "adverse selection" mechanism.
} 
effort. Such limitations in information processing bring to the fore the idea that salient factors within the information typically bias decision-makers (Fiske \& Taylor, 1991). For instance, the availability bias encourages decision-makers to recall salient information from memory (Tversky \& Kahneman, 1974). In addition, psychology literature has established the negativity bias, which is a predisposition to assign greater weight to negative events over good ones in decision-making (Baumeister, Bratslavsky, Finkenauer, \& Vohs, 2001; Rozin \& Royzman, 2001). The overemphasis on negative data in impression formation and recall research is well demonstrated in many studies (for reviews, see Peeters \& Czapinski, 1990; Rozin \& Royzman, 2001) that highlight how evaluators process and remember negative information more thoroughly than positive information when making judgments (Fiske, 1991).

The primacy of negative information related to withdrawal disproportionally attracts the attention of prospective VCs, leading them to discount other factors that might suggest that the focal venture would likely succeed. For example, VCs may overlook underlying strengths in the market, team, or financials if they give too much weight to the negative impact of $\mathrm{VC}$ withdrawal. As such, given "the danger of salient information (e.g., the lead entrepreneur is a winner) clouding the VC's judgment" (Zacharakis \& Meyer, 1998: 58), salient negative information changes the relative importance and use of information factors typically assessed in venture proposals (Franke, Gruber, Harhoff, \& Henkel, 2008; Zacharakis \& Shepherd, 2001). Evidence from recent behavioral research focusing on how investors make decisions has posited that they use a shortcut decision-making heuristic, known as elimination-byaspects, to reduce the number of available investment opportunities to a more manageable size (Maxwell, Jeffrey, \& Levesque, 2011). If an opportunity is diagnosed with a fatal flaw, it is rejected in the first stage of the decision-making process, but all other opportunities without fatal flaws progress beyond that stage. This non-compensatory strategy in decision-making 
likely excludes ventures with VC withdrawal from the "consideration" set of investors (Roberts \& Lattin, 1997) in the first stage of screening proposals. Therefore, we hypothesize:

Hypothesis 1. Withdrawal of VC investment ties decreases the valuation of the venture in the follow-on round of financing.

\section{Moderating the Factor of Uncertainty}

We have argued that in venture investing, where uncertainty makes the task of valuation challenging, markets will increasingly turn to other, non-traditional information cues such as insiders' continued financial commitment to help with evaluating ventures. However, not all ventures suffer from the same degree of informational uncertainty; for example, one factor that affects such uncertainty is the development stage of the venture. To bolster our confidence in the "adverse selection" channel, we investigate whether the effect of the above hypothesis is strongest when uncertainty is greatest (i.e., the venture is in the early stages of development as opposed to the late stages of development).

Uncertainty about a venture's prospects is reduced as the venture accumulates more resources and grows. Stinchcombe (1965) was the first to note "the liability of newness," which refers to the constellation of issues that newly founded ventures face that make them prone to failure. Schoonhoven, Eisenhardt, and Lyman (1990) consider the liability of innovation, whereby new ventures may fail in bringing innovative products to the market because of uncertainties in completing the first working prototype that delay the revenue generation needed to support the expenses. To overcome these liabilities, venture capitalists can use the strategy of staging their investments, which allows them to gather information and monitor the progress of ventures (Gompers, 1995). Conversely, entrepreneurs are willing to accept the process of staged capital to avoid dilution because they can demonstrate their own ability to meet targets (milestones) that provide objective data concerning the progress of their operations 
and resolve informational uncertainty. Consequently, the venture development stage affects the amount of information available to investors.

The stage of the venture development is a moderating factor in the relationship between the signal generated from VC withdrawal and the valuation. This is so because in the absence of sufficient information about the prospects of the venture to reach an independent conclusion, prospective investors place a higher value on signals, a point that is emphasized in the signaling literature (Spence, 1974). As a result, the actions of insider VCs should have a particularly strong effect on assessments of a venture's valuation when uncertainty is high. Conversely, when prospective investors are confident in their ability to assess a venture's quality based on its record of prior achievements, there is little need to infer its quality on the basis of secondary information about what the exchange partners do or their identities (Stuart et al., 1999). Overall, since the presence of information asymmetry is lower in the later stages of venture development (Hsu \& Ziedonis, 2013), the effect of signals on altering investors' perceptions declines.

\section{Hypothesis 2. The negative relationship between withdrawal of VC investment ties} and the valuation of the venture in the follow-on round of financing is amplified for early-stage deals compared with late-stage deals.

\section{New Joining Investors as a Mediating Mechanism}

The first reason why VC withdrawal decreases valuations is that it discourages new investors from joining the syndicate. We propose that the valuation benefits of new joining VCs are brought about through the increased incentive for insiders to obtain higher valuations.

As discussed previously, potential new investors interpret the $\mathrm{VC}$ withdrawal as a negative signal. To the extent that prospective investors perceive a higher risk of adverse selection for ventures with $\mathrm{VC}$ withdrawal, they would be less willing to enter potential collaborations with the focal venture. This observation is consistent with research highlighting the facilitating role of positive signals in improving a venture's chance of forming collaborative 
ties to obtain (complementary) resources (Ragozzino \& Reuer, 2011). Given that entrepreneurial ventures may have incentives to misrepresent their potential or exaggerate their prospects in order to attract partners (Cooper, Woo, \& Dunkelberg, 1988), potential partners value signals. Entrepreneurs, in turn, use signals to alter potential ventures' perceptions of the latent potential of the venture, thereby facilitating economic exchanges such as equity financing, alliances, or acquisitions (Gulati \& Higgins, 2003; Hsu, 2006; Ozmel et al., 2013; Pollock et al., 2010; Ragozzino \& Reuer, 2011). We therefore expect that VC withdrawal discourages new investors from joining the syndicate (VC withdrawal increases the likelihood that the follow-on round of financing is an "inside round," which refers to a round of funding composed of already existing investors.)

The decreased likelihood of new joining investors brought about by VC withdrawal decreases valuation for the following reason. The "outside round" is typically viewed as desirable because bringing new investors into an entrepreneurial venture is beneficial for the venture in terms of access to both the expertise and financial resources of the new investors as well as indicating a competitive valuation from an outside investor (Admati \& Pfleiderer, 1994). In an outside round, insider VCs (like the founder in the initial round of financing) typically have an incentive to push for a high valuation to minimize the dilutive effect of the round on their pre-existing interests in the venture. Consistently, follow-on financings in the VC industry are typically structured as outside rounds (Lerner, 1994). Broughman and Fried (2012: 1105) report that "according to almost every founder in our sample, existing VCs actively sought outside financing, and resorted to inside rounds only when outside financing was not available." Accordingly, we hypothesize:

Hypothesis 3. New joining VCs partially mediate the relationship between withdrawal of VC investment ties and the valuation of the venture in the follow-on round of financing. 


\section{The Quality of New Joining Investors as a Mediating Mechanism}

Whereas the literature has extensively considered the role of signals in enhancing market valuation or in facilitating access to partners (in isolation), the question remains whether signals improve the chances of new ventures attracting high-quality partners and, more importantly, the mediating effect associated with high-quality partners joining the syndicate. This research gap represents an important omission since potential exchange partners have idiosyncratic resources that form the basis of their competitive advantage and, by implication, their performance (Barney, 1991). For a new venture seeking investment ties, the consideration of the investors' resources (e.g., support network, human capital) is an important issue (Hellmann \& Puri, 2000, 2002; Ewens \& Rhodes-Kropf, 2015).

More broadly, a natural step in extending signaling theory in entrepreneurship and management is to relax the implicit assumption widely made in prior signaling studies (Ozmel et al., 2013; Stern et al., 2014) that partners hold fungible assets (here, cash for VCs) and instead focus on whether signals help materialize collaborations with partners with highly sought-after resources that shape the resource-based competitive advantage of the venture (Alvarez-Garrido \& Dushnitsky, 2015). In doing so, we address the inadequate attention given to the use of signaling theory to the strategic question of "who partners with whom" and its performance implications. This section focuses on two valuable intangible assets of exchange partners: organizational reputation and status.

While both the status and reputation of a firm are associated with perceived quality, research has attempted to delimit them by showing their interdependent, yet distinctive, roles in the social construction of markets (Pollock, Lee, Jin, \& Lashley, 2015; Sauder, Lynn, \& Podolny, 2012; Washington \& Zajac, 2005). Washington \& Zajac (2005: 283) summarize the key theoretical differences as follows: "Status is fundamentally a sociological concept that captures differences in social rank that generate privilege or discrimination (not performance- 
based awards), while reputation is fundamentally an economic concept that captures differences in perceived or actual quality or merit that generate earned, performance-based rewards." Whereas status reflects the position of a firm in a social hierarchy based on patterns of affiliations with those firms central in market networks (Podolny, 1993; Washington \& Zajac, 2005), reputation reflects expectations of a firm's future behavior based on observations of, or direct prior experience with, the firm. Additionally, status relates to perceived quality, particularly when uncertainty is high and quality is less directly observable than connections (Sauder et al., 2012). In contrast, reputation rests on a proven track record of delivering quality products or services. Research delimiting status and reputation in the VC context (e.g., Pollock et al., 2015) has considered the status of a VC firm as influenced by the status of the investors with whom the VC firm affiliates and the reputation of a VC firm as its ability to successfully exit portfolio ventures.

\section{The Mediating Role of the Status of New Joining Investors}

Withdrawal of VC investment ties decreases the likelihood of new joining VCs possessing high status. With uncertainty about market opportunities and the set of decisions that will best help realize those opportunities, it might be difficult for potential investors to know which opportunities or combination of exchange relations to pursue to achieve market success. Although new ventures prioritize collaboration with high-status VCs to benefit from their advantageous network positions as well as their legitimacy and visibility (Hallen, 2008; Milanov \& Shepherd, 2013), high-status VCs have many opportunities to allocate their scarce resources and must be selective. For instance, Podolny (2001) finds that high-status VC firms tend to avoid those investments with greater uncertainty. Indeed, allocating resources to the wrong opportunities can generate negative associations for $\mathrm{VC}$ firms, thereby undermining their status. Ventures with VC withdrawal elicit higher uncertainty than others, thus placing more strain on the prospective VC's status (related to the anxiety of compromising its status). 
Overall, VC withdrawal increases adverse selection risks, and considering that high-status VCs are highly selective, they further shy away from such ventures. Naturally, this means that the pool of remaining potential VC investors is comprised of those with lower status.

Affiliation with prominent VCs enhances the market valuation of new ventures because it signals that the new venture has superior prospects, resources, capabilities, and market opportunities for the following reasons (Gulati \& Higgins, 2003; Lee, Pollock, \& Jin, 2011; Ozmel et al., 2013; Pollock et al., 2010). First, prominent VCs have superior capabilities when selecting promising ventures and providing value-added services. Prominent VCs are better able to conduct due diligence by benefiting from their extensive information channels that are empowered by their connections in the VC syndicate networks. Additionally, prominent VCs attract better investment opportunities (Hsu, 2006). Given that they have achieved prominence through a series of prudent judgments about which ventures to back, their affiliation with a focal venture presumably represents another positive judgment.

Second, prominent VCs value their status highly and will act to reinforce their standing (Carter \& Manaster, 1990) in order to continue to enjoy the considerable advantages thereof (Podolny, 1994, 2001). Prominent VCs are quite selective when investing in entrepreneurial ventures, since investing in lower-quality ventures places a VC's own status at risk. To maintain other investors' trust in their decisions, high-status VCs put a lot of effort into making the right investment decisions (Gulati \& Higgins, 2003; Hsu, 2004, 2006), as evidenced by studies that document the superior performance associated with backing from prominent VCs (Hochberg et al., 2007). When it is costly to form and maintain inter-organizational relationships with prominent VCs, these relationships can generate important signals about a new venture's resources and prospects (Gulati \& Higgins, 2003; Ozmel et al., 2013). The signaling role of prominent VCs in enhancing the market valuation of investee firms is mostly documented in empirical studies of entrepreneurial ventures nearing IPO (Gulati \& Higgins, 
2003; Higgins \& Gulati, 2006; Fischer \& Pollock, 2004; Pollock et al., 2010; Stuart et al., 1999). ${ }^{7}$ Therefore, we suggest that one reason that VC withdrawal decreases venture valuation relates to how it deters prospective high-status VCs from joining the syndicate.

\begin{abstract}
Hypothesis 4. New joining VCs possessing high status partially mediate the relationship between the withdrawal of VC investment ties and the valuation of the venture in the follow-on round of financing.
\end{abstract}

\title{
The Mediating Role of the Reputation of New Joining Investors
}

Withdrawal of VC investment ties decreases the likelihood of new joining VCs possessing high reputations. Two observations help us understand why high-reputation VCs would be reluctant to pursue ventures with withdrawal. First, risking their reputation might create career concerns and lower than expected compensation, especially for VCs with high reputations. The reputations of VC firms (e.g., past performances in terms of taking portfolio ventures public) influence their ability to raise new funds and affects the amount of funds available for future investments (Gompers, 1996). A VC fund's past performance influences the inflow of new money (Sirri \& Tufano, 1998), and because (like other fund management companies) VCs are typically compensated by a fixed percentage of assets under management, they have financial incentives to increase their total assets under management. Second, VCs with high past performance are more attractive syndicate partners (Lerner, 1994) and their "merit-related" visibility enables them to increase their exposure to more opportunities across industries and markets (Sorenson \& Stuart, 2001). In this sense, to protect their reputation as a valuable asset, these VCs would be reluctant to pursue ventures with greater perceived risk, e.g., due to withdrawal.

\footnotetext{
${ }^{7}$ With less research focusing on the valuation of ventures prior to the IPO when the value of signals is arguably higher, we extend the scope of evidence in the literature.
} 
New ventures attempt to seek ties with high-reputation VCs to reap the greater substantive benefits offered by them, such as boosting research and development alliances (Hsu, 2006) and increasing the likelihood of going public (Hsu, 2006; Sorensen, 2007). Hsu (2004) reports that entrepreneurs are three times more likely to accept offers made by highreputation VCs. The involvement of reputable VCs likely contributes to enhancing the structure and governance of new ventures (perhaps through monitoring via participation in their boards of directors) (Hellmann \& Puri, 2002; Kaplan \& Stromberg, 2003; Wasserman, 2003) as well as helping to develop the business (Brander et al., 2002; Gorman \& Sahlman, 1989). Additionally, high-reputation VCs possess a screening ability that is almost twice as important as their value-added capabilities in explaining their performance track record (Sorenson, 2007). Thus, starting relationships with high-reputation VCs conveys the fact that new ventures have earned a positive evaluation, thereby boosting venture valuations and indicating that the venture has a higher probability of success. Therefore, we hypothesize that the reluctance of high-reputation VCs to join the syndicate partially accounts for the direct negative effect of signaling associated with VC withdrawal on venture valuation.

Hypothesis 5. New joining VCs possessing high reputation partially mediate the relationship between the withdrawal of $V C$ investment ties and the valuation of the venture in the follow-on round of financing.

\section{METHODS}

\section{Data and Sample}

We use the SDC Platinum database to build our sample of VC-backed ventures. This is one of the main commercial databases used by researchers (Gompers \& Lerner, 1999). The dataset includes information on investments (investment round date, valuation, amount, and VCs involved), VCs (affiliation, founding date, and geographic location), and ventures (industry, developmental stage at the date of each investment round, and exit status). We consider all the 
VC rounds of financing in the US from 1980 to 2014 . We apply the following filters to the data. First, we include ventures that were less than 10 years old when they received their first round of investment. Second, we limit our investigation to the influence of VC withdrawal at the second round of investment. These two filters provide us with reassurance that other signals that can accrue over time do not confound our results: these could include sales track records or meeting additional milestones in later rounds of financing. Third, to obtain reliable measures of successful exits for the ventures in our sample, we limit the sample to ventures that received their first round of investment prior to 2007 in order to allow at least seven years for an eventual exit from the venture (prior to 2014). ${ }^{8}$ Fourth, to calculate the reputation and status of each VC, we allow five years to pass from the beginning of the studied period in 1980, thereby restricting the sample to include only those ventures whose second round of investment was held after 1985. Fifth, we focus on investments in ventures located in the top five states in terms of VC funding (California, Massachusetts, New York, Pennsylvania, and Texas). In our database, more than $70 \%$ of the observations concern ventures in the top five states, suggesting that VCs are most active there. This geographical choice also reflects the potential concerns about the quality of data in smaller states. Given the competitiveness of these submarkets, to guarantee high-quality deal flows VCs tend to be "embedded" in their networks (Granovetter, 1985), which is a necessary condition for the efficient transfer and dissemination of information (VCs are immediately informed about the interactions of their syndicate partners with third parties). ${ }^{9}$ Sixth, we exclude observations (rounds) in which at least one investor is labeled an "undisclosed firm" in our dataset, because we identify the withdrawing VCs by the VC names provided by SDC Platinum. We check whether this filtering raises representativeness issues by

\footnotetext{
${ }^{8}$ As a robustness check, we included ventures that received the first round of financing before 2010 , and the results are very similar.

${ }^{9}$ To show that our results are robust to the geographical selection choice, we repeat our analysis of ventures on (i) all the states or (ii) alternatively, the two largest states in terms of VC activities (California and Massachusetts). The results (available upon request) presented in this study remain similar.
} 
comparing the distributions of investments across industries and states. In both cases, the deviation from the full sample is non-significant (the Chi-squares are 3.40 [n.s.] and 2.09 [n.s.], respectively). Finally, following Guler (2007) and Gompers and Lerner (1999), we correct the problem of overstating the rounds of financing in the SDC database by counting the separately recorded investments that occur in time intervals shorter than 90 days as one round. By applying the preceding filters, we obtain a final sample of 2,181 ventures. However, for the analysis related to valuation, we only use the 535 ventures with complete valuation data.

\section{Variables}

Valuation. This variable indicates the pre-money valuation of the venture in the second round of funding (in millions of US dollars, applying 2012 values). We log this variable to reduce skewness. Following prior research (Cumming \& Dai, 2013), for robustness we use Round size, the amount of funding, as an alternative indirect proxy for valuation, which also increases the sample size. For the subsample with the valuation data, the correlation between Round size and Valuation is $75 \%$. Round size, however, confounds valuation and the venture's cash needs. To the extent that including covariates, such as the stage of development and industry of the venture, captures some variance related to cash needs, then Round size can be a relevant proxy of valuation.

VC withdrawal. When at least one of the existing VCs withdraws from the follow-on round of financing, we code the observation related to that round of investment as $V C$ withdrawal. When a VC does not participate in the follow-on round of investment, $V C$ withdrawal equals 1 and 0 otherwise. We have only included the withdrawal by independent VC firms.

Early stage. We use a binary variable to indicate whether, in the second round, the development stage of the venture is Early stage (VentureXpert categories of "Seed stage" and "Early stage") or Late stage (VentureXpert categories of "Expansion stage" and "Late stage"). 
Outside round. We generate a binary variable that is equal to 1 when a new VC joins the second round and 0 otherwise.

VC status. A good proxy for VC status is centrality in syndicate networks (Guler, 2007; Hallen, 2008; Podolny, 2001; Pollock et al., 2015). We operationalized VC status using eigenvector centrality. In essence, eigenvector centrality measures the degree to which a focal actor is well connected to other well-connected actors in a given network of relationships (Bonacich, 1987). To create this measure, we used available data on all the VCs in our database, not just our sample. We constructed adjacency matrices that represent whether VCs are adjacent to other VCs (have co-invested in a venture) in the prior five years. Next, we calculate the largest eigenvector associated with the eigenvalue of the adjacency matrices. The eigenvector centrality assigns a higher score to a VC that has syndicated with VCs that have higher centrality scores (Pollock et al., 2015). The measure (VC centrality) is used as the maximum eigenvector centrality of all joining VCs. If there is no joining VC, we replace this value with zero. ${ }^{10}$

VC reputation. We use two measures that capture the quality of outputs based on the track records of VCs (Lee et al., 2011). These measures include the total number of rounds in which they have invested in portfolio ventures (VC general experience) and the number of portfolio ventures taken public (VC IPO experience). These measures are both based on the five years prior to the focal round of investment. Although correlated, these measures represent distinctive indicators of VC performance. ${ }^{11}$ First, the total number of rounds in which a VC has invested (VC general experience) captures the intensity of a VC's investment activity (Gompers et al., 2009). In addition to generating knowledge and experience for the VC, investment activity enhances the VC's visibility by bringing it into contact with more

\footnotetext{
${ }^{10}$ To ensure the robustness of the findings to this choice, we repeated our mediation analysis using only ventures that received outside round. The results remain similar and are available upon request.

${ }^{11} \mathrm{We}$ also used two other measures of reputation: Fund size and VC age. The results remain similar and are available upon request.
} 
investment opportunities and other VCs. Second, the number of portfolio ventures taken public (VC IPO experience) captures the extent to which VCs are able to select the most promising ventures (Lee \& Wahal, 2004) and add value to them in order to achieve a successful exit. Taking portfolio ventures public generates the majority of returns for investment funds, thus influencing the VC's ability to raise follow-on funds. These measures are used as maximum VC general experience and VC IPO experience of all joining VCs. If there is no joining VC, we replace these values with zero.

We include several variables to control for the characteristics of investors in the second round, the venture, and the market conditions. Regarding investors, we control for Syndicate size, which represents the number of VCs in the second round of investment. Syndicated investments may perform better by pooling the resources and expertise of syndicate members (Gompers \& Lerner, 1999).

Regarding venture characteristics, we control for investment size in the first round. First round size is logged to reduce right-skewness (in millions of US dollars, applying 2012 values). ${ }^{12}$ To control for a venture's geographical location, we include a dummy variable equal to 1 for California and 0 otherwise. We also control for industry fixed effects using the following industry classifications in SDC Platinum: Biotechnology, Communications, Computer Hardware, Computer Software, Consumer-Related, Industrial/Energy, InternetSpecific, Medical/Health, Semiconductors, and Other (the omitted category).

We control for general market conditions. First, we control for the size of the IPO market (IPO market size). In the year of VC investment, we count the number of IPOs (data sourced from Professor Jay Ritter's webpage at https://site.warrington.ufl.edu/ritter/ipo-data/) and $\log$ this variable. In the year of investment, we also count the number of VC rounds (and

\footnotetext{
12 The ideal control would be the first-round valuation. We are unable to use this variable because of data limitations (more than $70 \%$ of the values are missing in our dataset'.
} 
$\log$ this variable) to proxy the number of investment opportunities available in the market ( $V C$ market size). Finally, we include year fixed effects.

\section{Endogeneity of VC Withdrawal}

In the hypothesized relationships in this paper, unobservable factors (e.g., the quality of the venture) could influence both the decision of the withdrawing $\mathrm{VC}$ and the valuation, which would make the VC withdrawal endogenous. The "private information" channel biases the theoretically motivated effect of the "adverse selection" channel. Hence, ordinary least squares (OLS) estimates will likely be biased because they will capture both the average treatment effect of VC withdrawal and the bias caused by not controlling for the unobserved quality of the venture. For instance, a venture with lower unobserved quality in the second round of investment is more likely to both incur VC withdrawal and to receive a lower valuation.

To correct for this potential bias, we use the Heckman (1979) treatment effects model, taking into account the binary nature of our treatment. It is a special form of the Heckman selection model in which the outcome of the entire sample is observed as opposed to the outcomes of the "treatment," as in the case of a selection model. Treatment effect models are distinct from sample selection models (for a discussion on this, see Li \& Prabhala, 2007). Treatment effect models include the endogenous dummy variable as an independent regressor. Furthermore, for any given venture, we observe the outcome of a choice but not the outcomes of unmade choices. This missing information may result in a selection bias due to observables (e.g., failing to take into account observable characteristics, such as a venture's stage of development) or a selection bias due to unobservables. In addressing selection bias due to unobservables, Heckman (1979) proposes a two-step approach (for binary treatment choices) that estimates a choice model in the first stage. Following this estimation, a bias correction term (also known as the inverse Mills ratio [IMR]) is calculated and included in the second stage to estimate the effect of the treatment on the outcome. This method is a standard approach 
to correct for the endogeneity of binary treatments due to unobservables (Vella \& Verbeek, 1999).

To identify exclusion restrictions in Heckman's two-step approach, we use two variables. First, we use Other state deal growth. This variable measures the change in the annual total round of the $\mathrm{VC}$ investments between the year of the first investment round and the year of the second investment round in the state in which the first-round VCs were located (if the VCs were not in the same state as the investee ventures). This variable is set to 0 if the first-round $\mathrm{VC}$ and firm are from the same state, or if the first and second investment rounds are held within less than one year. ${ }^{13}$ We calculate this variable for each of the VCs involved in the first round of investment and take their maximum value to denote Other state deal growth. The idea is that when VCs have more investment opportunities in their own state, they have a greater incentive to focus their investments locally (e.g., to benefit from their information advantage), holding everything else constant.

Here is an illustration. Assume that a VC from the state of New York invests in the first investment round of a venture located in California in 2004. In 2005, when the venture is raising a second round of investment, the investment opportunities increase in the state of New York. The VC located there is more likely to withdraw its investment in California and is perhaps induced to focus on the growing opportunities in New York. This is true because proximity between VCs and their portfolio ventures allows the former to decrease their monitoring costs and provide better value-added services (Cumming \& Dai, 2010; Lerner, 1995), an explanation that is consistent with the documented local bias of VC investors. The ideal instrument to identify the causal impact of VC withdrawal would be to randomize it, as this ensures no systematic ex-ante differences between ventures with experience of VC withdrawal and those

\footnotetext{
${ }^{13}$ In the case of foreign VCs, we calculate Canadian VC activities at the Canadian provincial level (due to proximity) and other foreign $\mathrm{VC}$ activities at the country level.
} 
without. However, the exclusion restriction necessitates that the variable Other state deal growth be solely uncorrelated with the unobserved quality of the focal venture. There is no reason to believe that changes in investment opportunities in another state (in our example, the state of New York) relate to the unobserved quality of the focal venture (in our example, a venture located in the state of California). The opportunity set of the out-of-state VC varies (owing to greater VC demand in its home state since its initial investment in the focal venture), regardless of the underlying quality of the portfolio venture. Hence, this variable satisfies the requirements of both relevance and exogeneity. It is noteworthy to add that Other state deal growth in our data is not correlated with our performance-related dependent variables but is correlated with VC withdrawal $(0.19, p<0.001)$.

Second, we use Distance, which refers to the maximum in the set of geographic distances between first-round VCs and the venture. Geographical proximity between VCs and ventures reduces the level of information asymmetry and increases the probability of VC financing; like other investors, VCs tend to invest locally owing to their information advantage (Cumming \& Dai, 2010; Lerner, 1995; Sorenson \& Stuart, 2001). On the one hand, VCs with geographical proximity can spend more time on-site and increase their involvement and support through frequent interactions with ventures (Gorman \& Sahlman, 1989). On the other hand, VCs without such proximity should possess certain abilities or characteristics (e.g., greater experience or reputation) that motivate them to invest from a distance (and those characteristics should enable them to overcome geographic barriers once they invest). Ex ante, it would not be rational for a $\mathrm{VC}$ to have invested in a distant venture unless it expected that it would to be able to overcome the geographical barriers inherent in selection and value-added ex post (Sorenson \& Stuart, 2001). Thus, we expect an equivocal relationship between performance and distance (conditional on investment by a distant VC). Despite the potentially weak exogeneity of this variable, note that Distance is significantly correlated with VC 
withdrawal $(0.16, p<0.001)$ but not correlated with the financial and non-financial outcomes in our sample. If we exclude this variable from our analysis, our results remain similar. ${ }^{14} \mathrm{We}$ $\log$ this variable to suggest decreasing the marginal costs of distance, following prior work (Sorenson \& Stuart, 2001).

As additional controls in the treatment equation, we use Syndication diversity. To address concerns over heterogeneity in organizational affiliation and potential conflicts of interest from pursuing different objectives, Syndication diversity counts the number of firstround VCs with different affiliations (these include Independent VC, Corporate VC, Bankrelated VC, Angels Groups, and others). This variable can obtain a value between 1 and 5 (alternatively, we use syndicate size). ${ }^{15}$

\section{RESULTS}

Table 1 shows the descriptive statistics and the pairwise correlation matrix. About $24.3 \%$ of the ventures experienced VC withdrawal.

\section{[Table 1 and Table 2 about here]}

Table 2 shows the results of the multivariate analysis. We first check the variance inflation factor (VIF) and find little concern for issues of multicollinearity in our estimates (VIF values are less than 5). As discussed before, because the OLS estimate can be biased due to the endogeneity arising from VC withdrawal, we employ the Heckman treatment effects model to obtain unbiased estimates of VC withdrawal.

14 To operationalize Distance $_{i}$, following Cumming and Dai (2010), we calculated the geographical distance using a great circle equation: $d_{i j}=3,963 \operatorname{Arcos}\left[\sin \left(l t_{i}\right) \sin \left(l t_{j}\right)+\cos \left(l t_{i}\right) \cos \left(l t_{j}\right) \cos \left(l g_{i}-\right.\right.$ $\left.l g_{j}\right)$ ], where $d_{i j}$ is the distance in miles between $\mathrm{VC} i$ and venture $j$; lt and $l g$ are latitude and longitude, respectively, in radians for each zip code obtained from the US Census Bureau's Gazetteer (http://www.census.gov/geo/maps-data/data/gazetteer.html). For foreign VCs, we collected the latitude and longitude of the capital of the country in which the VC is based. Among the set of first-round VCs, Distance is the largest value of $d_{i j}$.

${ }^{15}$ In an unreported analysis, we use several other variables: (i) the age of the oldest fund among VCs (the older fund might be closer to the end of its life and have less money left to invest), (ii) differences between the sizes of funds in the first round (size differences might imply divergent portfolio approaches and risk exposures, see Nanda \& Rhodes-Kropf, 2017), and (iii) differences between the sizes of funds in the first round. The results from including these variables remain similar and are available upon request. 
Panel B of Table 2 shows the results of the first-stage estimates (treatment equation), which predict the probability of $V C$ withdrawal and are used to estimate the IMR, denoted by Lambda in the tables. Panel A of Table 2 shows the results of the second-stage estimates. Model 1 of Panel A $(N=535)$ suggests that $V C$ withdrawal has a negative effect on the Valuation ( $b$ $=-0.418, p<0.05)$, providing support for H1. In terms of economic magnitude, $V C$ withdrawal reduces the Valuation by $34.1 \%$ in comparison with ventures that enjoy the continued commitment of all existing investors (comparison group). For a robustness check, we reapply the Heckman treatment effects model on Round size $(N=2,181)$ and present the estimates in Model 2 in Table 2 (Panels A and B). The results remain consistent and support H1. VC withdrawal reduces the Round size by $61.6 \%(b=-0.956, p<0.01)$.

We note some significant relationships in Models 1 and 2 in Panel B, Table 2. In predicting the likelihood of $V C$ withdrawal, Other state deal growth $(p<0.1)$ and Distance are positive ( $p<0.05$ and $p<0.01$, respectively). Additionally, Syndication diversity is positive ( $p$ $<0.01$ ), indicating that a possible goal mismatch between investors with different affiliations (e.g., independent investors, corporate investors, etc.) is associated with a higher likelihood of VC withdrawal. Following Cameron and Triveldi (2009), we also use two-stage least squares (2SLS) to show that our results are robust to the choice of specification. These results are presented in Appendix 1. A benefit of using 2SLS is its ability to test whether VC withdrawal is endogenous, given our choice of instruments. We use the Durbin-Wu-Hausman (DWH) test. Under the null hypothesis, $V C$ withdrawal is exogenous. The DWH test suggests that we can reject the exogeneity of $V C$ withdrawal $(p=0.023)$. Furthermore, the F-statistic obtained from first-stage regression (28.043) is larger than the critical value of 10, which indicates that our instrumental variables are not weak (Stock \& Yogo, 2005). We further show that our model does not violate the overidentifying restriction, and we cannot reject the null hypothesis that our instruments are valid $(p=0.534)$. The R-squared of the first stage is also 0.210 . These 
preceding statistics reassure us that the instrumental variables are relevant and valid. The results obtained from this exercise further support our prior findings.

To test $\mathrm{H} 2$, we include an interaction between $V C$ withdrawal and Early stage dummy (Model 3 in Table 2). The interaction coefficient is negative and statistically significant $(b=-$ $0.287, p<0.1$ ), which supports $\mathrm{H} 2$. Because there are inconsistency concerns over interactions involving one endogenous variable that might produce biased estimates (Wooldridge, 2010:, we split the sample and redo the previous analysis based on whether the venture is in the Early stage or not. Like the results of Model 3, Models 4 and 5 suggest that the negative effect of VC withdrawal is greater in economic magnitude for early-stage ventures (Model 4: $b=-1.106, p$ $<0.1)$ than late-stage ventures $(b=-0.230$, n.s. $)$. Further unreported tests also show that the negative effect of withdrawal is only statistically significant in subsamples composed of the second round of investments, but not in later rounds.

Now we turn our attention to the mediation effects proposed in $\mathrm{H} 3, \mathrm{H} 4$, and $\mathrm{H} 5$. To test the mediation effect, we employ the method first used by Baron and Kenny (1986) that specifies OLS regression models. However, we modify this method and use the Heckman treatment model because our main independent variable ( $V C$ withdrawal) is endogenous. Baron and Kenny's (1986) procedure involves estimating three separate regression equations. In the first step, Valuation is regressed on VC withdrawal and the control variables (Table 3, Model 5). ${ }^{16}$ In the second step, we regress mediating variables on VC withdrawal (Table 3, Models 1-4). The mediating variables include outside round, VC centrality, VC general experience, and $V C$ IPO experience. In the final step of the mediation analysis, Valuation is regressed on $V C$ withdrawal, mediating variables, and the control variables (Table 3, Models 6-9). While VC withdrawal influences VC valuation and mediating factors in the two initial steps, to establish

\footnotetext{
16 This model is identical to Model 1 in Table 2; however, we report it again to facilitate visual comparison across subsequent models.
} 
mediation, the effect of VC withdrawal on Valuation is also smaller in absolute terms when mediators are included (step 3), compared with the exclusion of mediators (step 1).

\section{[Table 3 about here]}

The results presented in Table 3 (Models 1-4) indicate that $V C$ withdrawal has negative and statistically significant effects on all mediators: Outside round $(b=-0.230, p<0.05), V C$ centrality $(b=-0.024, p<0.05)$, VC general experience $(b=-1.343, p<0.05)$, and VC IPO experience $(b=-0.648, p<0.05)$. When including these mediators in a regression of valuation on VC withdrawal in Table 3 (Models 6-9), we find that the effect of VC withdrawal on venture valuation reduces in absolute terms relative to models excluding these mediators (Model 5 compared with Models 6-9). Note that mediators have positive and statistically significant effects on valuation, as expected. For further robustness tests, we repeat the same analysis on the larger sample $(\mathrm{N}=2,181)$ using Round size as the main dependent variable. The results (Appendix 2) are like those presented in Table 3. This analysis is especially important since small samples may not meet the distributional assumptions underlying mediation tests like the Sobel test (Fritz \& MacKinnon, 2007). In our test of the mediation effect, we also use bootstrapping as proposed by Preacher and Hayes (2004). The test confirms the statistical significance of the mediating effects of Outside round $(\mathrm{z}=-5.17, \mathrm{p}<0.01)$, VC centrality $(\mathrm{z}=$ $-4.914, \mathrm{p}<0.01)$, VC general experience $(\mathrm{z}=-6.339, \mathrm{p}<0.01)$, and VC IPO experience $(\mathrm{z}=-$ $6.253, \mathrm{p}<0.01) .{ }^{17}$

\section{Alternative Explanations, Additional Analysis, and Robustness Checks}

We discuss a few alternative explanations for $\mathrm{H} 1$. The foremost issue is the challenge of distinguishing between the "private information" channel and the "adverse selection" channel. In addition to our efforts to treat "private information" on venture quality revealed after

\footnotetext{
${ }^{17}$ For robustness, we repeated the Sobel test on the small sample as well $(\mathrm{N}=535)$. The test confirms the mediating effects of outside round $(\mathrm{z}=-1.96, \mathrm{p}=0.050), V C$ centrality $(\mathrm{z}=-1.91, \mathrm{p}=0.056)$, VC general experience $(\mathrm{z}=-1.98, \mathrm{p}<0.048)$, and VCIPO experience $(\mathrm{z}=-1.94, \mathrm{p}=0.052)$.
} 
investment as an omitted variable, and by using appropriate specifications such as Heckman treatment models or 2SLS to address potential endogeneity due to omitted variable bias, a few other observations and tests are worthy of mention. First, we obtain similar results when we restrict our analysis to the subsample of ventures that have successfully exited (IPO or Merger \& Acquisition). This sample is comprised of ex-post, high-quality ventures that were less likely to be at risk of performing poorly at the time of $\mathrm{VC}$ withdrawal. Thus, to the extent that reasons unrelated to low (expected) performance motivated the withdrawal (for this subsample of ventures), the negative effect of withdrawal should be taken as evidence of the "adverse selection" channel. Second, since we cannot directly observe the private information known by the investor leaving the syndicate, our best effort is to find proxies that potentially correlate with it. One candidate is the long-term outcome of the venture. Controlling for Successful exit in the treatment equations captures some of the unobservable "private information." We obtain similar results. Accordingly, our current results should be net of "private information," which is correlated with Successful exit.

Third, we suspect that more "private information" is the most important driver of VC withdrawal. A proxy for the availability of information or the ease of access to such information is the proximity of the investor to the venture. Our first-stage regressions predicting who leaves the syndicate suggest that an investor's likelihood of withdrawal increases with distance. Therefore, if anything, the data seems to suggest that less "private information" (either positive or negative) is more likely to be associated with withdrawal. To corroborate this further, since Distance measures the most distant investor among the syndicate members (operationalized as a round-level construct), we perform a venture fixed-effect analysis at the level of venture round-VC (and measure distance in the dyad VC firm-venture). To illustrate, if five different VCs participated in the first funding round, we have five observations for that venture round. Venture fixed effects alleviate concerns related to the (time-invariant) unobserved quality of 
the venture. The results (available from authors upon request) again show that more distant VCs within a syndicate are more likely to withdraw their investment from a venture of given quality. ${ }^{18}$ Our further investigations show that $86 \%(81 \%)$ of VCs in our sample that withdraw their investment are located more than 100 (200) miles away from the venture. Per prior research (e.g., Lerner, 1995), VCs located more than 100 miles from the venture are less likely to be board members and thus less likely to be involved in the daily activities of the venture. Hence, it is less likely that distant VCs that withdraw do so because of their access to more private information.

Fourth, lead VCs (defined as the VCs that invested the largest amount in prior rounds of investment) actively participate in the day-to-day activities of the venture and sit on the board of directors (Lerner, 1995). Hence, they are more likely to have more "private information." We use sub-sample analysis to compare withdrawal by lead VCs and withdrawal by non-lead VCs. The results (available from authors upon request) show that there is no statistically significant difference in the negative effects between withdrawal by lead and nonlead VCs.

Fifth, for further methodological robustness, we employ propensity score matching to test $\mathrm{H} 1$. The rationale is as follows. Ventures with and without the experience of $\mathrm{VC}$ withdrawal could differ on both observable and unobservable characteristics (that is, ventures that experience $\mathrm{VC}$ withdrawal may not be a random sample of ventures). The technique of propensity score matching allows us to create, based on observable characteristics, "twin" ventures without the experience of VC withdrawal (control group) but that are as similar as possible to the ventures experiencing VC withdrawal (treatment group). The underlying assumption is that variation in unobservables and their influence (e.g., private information) is

\footnotetext{
${ }^{18} \mathrm{We}$ also find (controlling for venture quality) the variable Other state deal growth is positively correlated to $\mathrm{VC}$ withdrawal, which increases our confidence in the choice of Other state deal growth as a reliable instrumental variable.
} 
lower when both groups have similar observables. We considered the first nearest neighbor and used all the control variables (listed in Table 2) in a probit estimation of the treatment group. After checking that the treatment and control groups were balanced, we ran Heckman treatment regressions (Appendix 3). The results provide similar evidence in support of $\mathrm{H} 1$, albeit statistically non-significant results for valuation due to the small sample size.

Sixth, we also employ a difference-in-difference strategy inspired by Townsend (2015), who has shown that VCs with higher exposure to the Internet industry became more likely to withdraw their investment in non-information technology related ventures after the burst of the Dot Com bubble. This observation allows for exploiting the Internet exposure of VCs as a treatment variable in a difference-in-difference framework. More formally, Internet exposure for each VC firm is the share of the focal VC investments in the Internet sector in the 10 years prior to March 31, 2000 , the peak of the Dot Com bubble (Townsend, 2015). Given our interest in all the investors involved in the first investment round, we define Internet exposure as the maximum value of Internet exposure for VCs that participated in the first round of investment. Furthermore, we limit our sample to non-IT entrepreneurial ventures that received their first round of investment in the pre-bubble period (March 31, 1997 to March 30, 2000) and their second round of investment in the post-bubble period (March 31, 2000 to March 31, 2003). The data filtered comprise 340 observations (170 ventures). Thus, each venture appears twice, in which the first round is prior to the bubble and the second round is after the bubble. This identification strategy also allows us to include venture fixed effects, controlling for the ventures' time-invariant characteristics. The estimation results are presented in Appendix 4. We obtain the negative treatment effect $(p<0.05)$ in both the models without and with the venture fixed effect (Models 1 and 2, respectively). ${ }^{19}$ These results are consistent with our prior

\footnotetext{
${ }^{19}$ Due to the very small sample size of 26 , we are not able to repeat the sample analysis for the valuation variable.
} 
findings and show that non-IT ventures that received investment in the first round of investment from VCs with higher Internet exposure experience a lower Round size in the second investment round. Given that diffusion of the shock in the private investment market of Internet ventures to non-IT sectors is unlikely to reflect the change in the quality of the investee venture (with withdrawing experience), our results suggest that $\mathrm{VC}$ withdrawal, which is more likely in the treatment group, as shown by Townsend (2015), has negative implications for the ability of the ventures in that group (non-IT) to raise subsequent financing.

We now explore some other issues that may have confounded our results (the estimates are available upon request.). First, we control for the investment that the withdrawing VC made in the first round to address the concern that withdrawal may lead to a financing gap and that the syndicate will have less money to contribute to the second funding round. ${ }^{20}$ The results remain similar. Second, because we only observe the outcome of $V C$ withdrawal for the ventures that receive at least a second round of financing, our results might be subject to sample selection bias. To address this issue, we employ the Heckman selection model. In the first stage, we estimate whether the venture receives more than one round of financing in a probit specification; next, we obtain and include the IMR in the second-stage regression. After controlling for sample selection, the results are very similar to the main analysis.

\section{Long-term Performance Implications of VC Withdrawal}

Unlike the extensive evidence of signals in entrepreneurship and management, few studies have assessed the influence of signals over time (e.g., Gulati and Higgins, 2003). The theoretical expectation is that the effects of signals deteriorate once evaluators can obtain additional new disconfirming information or can acquire direct experience (Pollock \& Gulati, 2007). Therefore, the long-term performance of the venture is unlikely to be tarnished by its VC withdrawal experience if the theoretical channel of the VC withdrawal effect is "adverse

\footnotetext{
${ }^{20}$ We thank an anonymous reviewer for this comment.
} 
selection" and the availability of new information over time compensates for the temporary negative perceptions of the venture's quality. However, it is possible that the long-term performance of new ventures is adversely affected by lack of access to high-quality investors (triggered by VC withdrawal) (Sorenson, 2007), which is supported by studies that document the superior performance associated with backing from prominent VCs (Hochberg et al., 2007).

To test which effect prevails, we investigate whether there are statistically significant differences in the successful exits of ventures depending on $V C$ withdrawal. Our estimates indicate no statistically significant relationship between VC withdrawal and the successful exit (defined as IPO or M\&A) of the venture (Appendix 5). We also manually collected data on the date of IPO or M\&A and estimated the hazard of success (i.e., the average time between the second round of investment and exit is 1,542 days). Like the probability of success, the hazard of success is not statistically different. Similarly, Townsend (2015) finds that while the propagation of financial shock reduces the hazard of receiving a new round of VC financing, it does not have any statistically significant effect on the hazard of success. Overall, many other events could influence the exit outcome after the second round of investment, and our evidence suggests that the effect of $\mathrm{VC}$ withdrawal is less pronounced over time as more tangible information surfaces.

\section{Heterogeneity of Withdrawing VC}

The signaling role of affiliation with prestigious third parties, such as high-status VCs, in enhancing the market valuation of ventures is widely documented in empirical studies of entrepreneurial ventures nearing IPO (Gulati \& Higgins, 2003; Pollock et al., 2010; Stuart et al., 1999). Such affiliations can send signals of a venture's quality by certification and endorsement, especially when direct indicators of quality are missing or difficult to observe (Sanders \& Boivie, 2004). Here, the signaling costs are borne largely by the third parties given that the prestigious third parties put their own reputational capital at risk by endorsing the 
venture. Therefore, we hypothesize that the withdrawal of investment ties from high-status VCs decreases the valuation of the venture in the follow-on round of financing more than the withdrawal of low-status VC investment ties.

To investigate the dependence of Valuation and Round size on the characteristics of the withdrawing VC (high-status versus low-status VC withdrawal), we split the sample based on the status of the withdrawing VC because in our specifications we can only address one endogenous binary treatment variable. Our (unreported) regressions predicting Valuation suggest there is no statistically significant difference between High-status VC withdrawal $(b=$ -0.364 , n.s.) and Low-status VC withdrawal ( $b=-0.396$, n.s.). Similarly, while High-status VC withdrawal reduces the Round size by $75 \%(b=-1.362, p<0.01)$, this magnitude is $67 \%$ for Low-status VC withdrawal $(b=-1.181, p<0.01)$. These coefficients are not statistically different from each other. We suspect that the limited number of High-status VC withdrawals ( $N=15$ and $N=62$, depending on whether the dependent variable is Valuation or Round size) in the data may reduce the statistical power needed to identify the cross-sectional differences. ${ }^{21}$

\section{DISCUSSION}

This study examines the impact of withdrawn relationships on entrepreneurial ventures' performance. We conceptualized how the withdrawal of investment ties disseminates negative information, the spread of which negatively impacts the fundraising performance of entrepreneurial ventures. Using a dataset covering 22 years of VC investments, we tested our conjectures and found support for our predictions. Ventures that experience withdrawal face lower valuations and are less able to acquire financial resources, particularly as a result of difficulty in partnering with new prospective VCs (especially high-status and high-reputation ones). Overall, our study extends the understanding of the financial and non-financial

${ }^{21}$ We also have found evidence that withdrawal by high-reputation VCs has a greater effect on a venture's Valuation and Round size than that of low-reputation VCs. However, these differences are not statistically different from each other. 
performance consequences of new ventures' ties, formed under uncertainty, that have subsequently gone awry.

This paper offers several contributions. First, we add to the literature on discontinuations of inter-organizational relationships. The main focus of this literature has been on the antecedents of withdrawals (Greve et al., 2010; Greve et al., 2013; Guler, 2007; Li \& Chi, 2013; Polidoro, Ahuja, \& Mitchell, 2011), giving predictions that are distinct from those of tie formation studies. For instance, Li and Chi (2013) highlight the influence of portfolio configurations of VCs (such as portfolio diversity) on the propensity to withdraw from a portfolio venture. Our study not only complements these studies by highlighting that the propensity of tie discontinuation is correlated with factors such as potential principal-principal agency conflicts (related to the diverse affiliations of investors in the syndicate) or growth in outside options (e.g., nearby investments favored by investors), but our work also adds to the limited knowledge of what happens "after the break-up." Whereas Zhelyazkov and Gulati (2016) exceptionally focus on VC firms and find that VC firms that withdraw their investments suffer negative relational consequences, which reduces the likelihood of them entering into subsequent exchanges, we focus on the consequences of $\mathrm{VC}$ withdrawal for entrepreneurial ventures.

Second, our study contributes to research on inter-organizational relationships and performance, with an emphasis on entrepreneurial ventures (Baum et al., 2000). Prior work has often presented ties as a means of achieving competitive advantage and sustained performance; however, given the uncertainties in the development of entrepreneurial ventures, there remain circumstances in which these early investment relationships are discontinued (to both parties' detriment). We marshaled new evidence about the potential negative (and perhaps unintended) consequences for entrepreneurial ventures when early relationships are discontinued. We theorized that the discontinuation of ties could negatively impact an entrepreneurial venture's 
valuation and its prospective partners. Specifically, we examined how a lack of interest from prospective reputable and high-status partners, as two possibly desirable characteristics in a partner, mediates the effect of $\mathrm{VC}$ withdrawal on valuation. Our theoretical perspective also adds to the ongoing conversation about the effects that signals have on (i) financial outcomes, mostly studied around the time of IPO (Gulati \& Higgins, 2003; Megginson \& Weiss, 1991; Sanders \& Boivie, 2004; Stuart et al., 1999), and (ii) economic exchanges, such as equity financing, alliances, or acquisitions (Hsu, 2006; Ozmel et al., 2013; Pollock et al., 2010; Ragozzino \& Reuer, 2011). Unlike these previous studies that explore signaling opportunities for young or recent-IPO ventures, our study first embraces heterogeneity in the quality of exchange partners as a relevant outcome of signaling (i.e., how signals influence tie formation with exchange parties possessing high-quality resources). Second, we show that outcomes of signaling are interlinked: adverse selection concerns deter partnering with organizations possessing more attractive resources, and ultimately the availability of these exchange partners mediates the relationship between signals and valuation.

The present study highlights how non-repetition of ties from some partners in the syndicate influences partner selection decisions. Researchers have investigated various opportunities and challenges that shape preferences and drive tie formation (Diestre \& Rajagopalan, 2012; Rothaermel \& Boeker, 2008; Vissa, 2011), including concerns over asymmetric information between partners (Ragozzino \& Reuer, 2011). While each party exerts efforts to conduct due diligence during the process of initiating the tie, partners with knowledge/information pertinent to the partnership may be unable or unwilling to share it (given their natural incentive to misrepresent their prospects in order to entice their partners to enter collaborations or command higher prices for their products). Therefore, information asymmetries may lead to a combination of the following outcomes: partnerships fail to form even though they could benefit both partners or one side of the exchange party receives 
discounted offer prices (e.g., in acquisitions of equity) because the other side of the exchange party confronts the problem of adverse selection. This work highlights how non-repetition of ties in the investment syndicate leads to the latter effect, which is partially mediated by the former effect (by theorizing that non-repetition of ties conveys potential adverse selection risks). This contribution implies a new pathway into how prior patterns of tie formation have a lasting influence on future tie formation (Baum, Shipilov, \& Rowley, 2003; Chung et al., 2000; Gulati, 1995), which complements prior research efforts that emphasize other desirable attributes in repeated partners, such as trust and protection against misappropriation risks. Because withdrawal induces adverse selection risks for the current investment and impacts the short-term prospects of the underlying venture, our results implicitly shed new light onto the findings of Zhelyazkov and Gulati (2016) that suggest that withdrawal events can break the inertial preference for repeat and structurally proximate ties, which is observed in prior research on network churn (Rowley, Greve, Rao, Baum, \& Shipilov, 2005).

One finding that is worthy of additional discussion relates to how diversely syndicated deals are more prone to non-repetition of ties. VC syndicates are characterized as business relationships composed of investors with different incentives, objectives, and cash flow rights (Nanda \& Rhodes-Kropf, 2017). Such arrangements are fraught with frictions that can generate potential downsides for investors and entrepreneurs. To illustrate, corporate VCs pursue strategic objectives rather than financial returns alone (Dushnitsky, 2012), and incongruent objectives among investors may create conflicts of interest over priorities of the venture goals and changes in the strategic direction of new ventures. In addition to issues such as potential free-riding behavior ensuing from decreased ownership stakes in larger syndicates, coordination costs, such as collective monitoring of the entrepreneurs and controlling managerial opportunism, increase with diversity. For these reasons, the positive correlation between syndicate diversity and non-repetition of ties imply that the composition of VC syndicates has 
real consequences for the portfolio ventures, perhaps due to incentive differences and coordination frictions within VC syndicates.

Non-repetition of ties in our context may involve retaining the VC's (diluted) equity in the venture while stopping investment in subsequent rounds. In this case, the VC discontinues its investment without terminating its relationship with the syndicate partners. VentureXpert does not allow us to distinguish between retention and sale of equity by discontinuing investors. Because retention of equity by discontinuing investor(s) in the non-repetition of tie is likely to have weaker effects on the valuation compared with the private sale of equity, inclusion of both cases would weaken our predictions. For this reason, our empirical estimates are conservative given the possible existence of cases in which a $\mathrm{VC}$ does not divest its stake after discontinuing.

\section{Managerial Implications}

Our study may be useful for entrepreneurs and VCs navigating early investment relationships. The suggestion to accept investment from high-status VCs may be overly simplistic advice to give to entrepreneurs. From a normative standpoint, our results indicate that entrepreneurs should be wary of whether VCs view the seed and early-stage investments as cheap options (VCs pursuing an "option portfolio" strategy versus investing because they are convinced by, and committed to, supporting the venture). Rather, entrepreneurs should choose investors that act with conviction and tend to be engaged and committed. Nevertheless, sourcing money from a top-tier fund at any point in the development of the venture is a double-edged sword; while it maximizes the chances of success, provided that the venture performs well, it can ruin the chances of success if the investor (even for idiosyncratic reasons) later decides to discontinue. Accordingly, while entrepreneurs can take the money and leverage the advice, status, and network, they should be wary that a VC may not back them in the future and that the competitive advantage they gain (in recruitment, closing clients or partners, attracting media attention, etc.) may become an anchor around their neck. 
Our results also have some implications for VCs and the syndicate partners they choose. VCs need to be careful about choosing their partner(s) to avoid scenarios (such as the one studied here) that put their investments at risk of losing opportunities to develop and grow.

\section{Limitations and Future Research}

Our study's limitations present several avenues for future research. One is linked to the drawbacks of our research setting of one type of intermediary organization (VC), raising the question of the extent to which our findings can be generalized to other relationships. Future research may profitably explore other relationships (e.g., client relationships, as in Rogan \& Sorenson, 2014, or alliance relationships) to determine whether negative signals from the termination of relationships similarly undermine the focal firm's reliability. There is evidence that the spread of negative information (e.g., unethical corporate acts) damages an organization's network partners (Sullivan, Haunschild, \& Page, 2007). The dynamics we identified may be relevant to environments with extensive uncertainty about the quality of the firms. The negative impacts may be less important in environments that offer rich information.

In this paper, we analyzed VC syndicate networks because they are especially important networks for new ventures with resource constraints. However, we believe that our arguments might be generalized to the networks of alliances for new firms provided that (i) potential partners face adverse selection risk and (ii) existing alliance partners are expected to continue but dissolve their ties. When these two conditions hold, our hypotheses can be applied to other types of inter-organizational relationships, such as alliance relationships.

In addition, there are other ways that new ventures can signal their value regardless of withdrawal (e.g., patenting or enlisting prestigious board members), so it would also be valuable to examine whether such factors weaken the effect of $\mathrm{VC}$ withdrawal, or any other 
type of unexpected termination of relationships, on the ability of ventures to subsequently form

worthwhile collaborations.

\section{REFERENCES}

Admati, A. R., \& Pfleiderer, P. 1994. Robust financial contracting and the role of venture capitalists. The Journal of Finance, 49(2): 371-402.

Akerlof, G. A. 1970. The market for "lemons": quality uncertainty and the market mechanism. The Quarterly Journal of Economics, 84(3): 488-500.

Alvarez-Garrido, E., \& Dushnitsky, G. 2015. Are entrepreneurial venture's innovation rates sensitive to investor complementary assets? Comparing biotech ventures backed by corporate and independent VCs. Strategic Management Journal: 37(5): 819-834.

Barney, J. 1991. Firm resources and sustained competitive advantage. Journal of Management, 17(1): 99-120.

Baron, R. M., \& Kenny, D. A. 1986. The moderator-mediator variable distinction in social psychological research: Conceptual, strategic, and statistical considerations. Journal of Personality and Social Psychology, 51(6): 1173.

Baumeister, R. F., Bratslavsky, E., Finkenauer, C., \& Vohs, K. D. 2001. Bad is stronger than good. Review of General Psychology, 5(4): 323-370.

Baum, J. A., Calabrese, T., \& Silverman, B. S. 2000. Don't go it alone: Alliance network composition and startups' performance in Canadian biotechnology. Strategic Management Journal, 21(3): 267-294.

Baum, J. A., Shipilov, A. V., \& Rowley, T. J. 2003. Where do small worlds come from?. Industrial and Corporate Change, 12(4): 697-725.

Baum, J. A. C., Rowley, T. J., Shipilov, A. V., \& Chuang, Y. T. 2005. Dancing with strangers: aspiration performance and the search for underwriting syndicate partners. Administrative Science Quarterly, 50(4): 536-575.

Bernstein, S., Giroud, X., \& Townsend, R. R. 2016. The Impact of Venture Capital Monitoring. The Journal of Finance, 71(4): 1591-1622.

Block, J., Miller, D., Jaskiewicz, P., \& Spiegel, F. 2013. Economic and technological importance of innovations in large family and founder firms: An analysis of patent data. Family Business Review, 26(2),:180-199.

Bonacich, P. 1987. Power and centrality: a family of measures. American Journal of Sociology, 92(5): 1170-1182.

Brander, J. A., Amit, R., \& Antweiler, W. 2002. Venture-capital syndication: Improved venture selection vs. the value-added hypothesis. Journal of Economics \& Management Strategy, 11(3): 423-452.

Broughman, B. J., \& Fried, J. M. 2012. Do VCs use inside rounds to dilute founders? Some evidence from Silicon Valley. Journal of Corporate Finance, 18(5): 1104-1120.

Bygrave, W. D. (1987). Syndicated investments by venture capital firms: A networking perspective. Journal of Business Venturing, 2(2): 139-154.

Cameron, A. C., \& Triveldi, P. K. 2009. Microeconometrics Using Stata. College Station, Texas: Stata Press.

Carter, R., \& Manaster, S. 1990. Initial public offerings and underwriter reputation. The Journal of Finance, 45(4): 1045-1067.

Chung, S., Singh, H., \& Lee, K. 2000. Complementarity, status similarity and social capital as drivers of alliance formation. Strategic Management Journal, 21(1): 1-22.

Certo, S. T. 2003. Influencing initial public offering investors with prestige: Signaling with board structures. Academy of Management Review, 28(3): 432-446.

Certo, S. T., Daily, C. M., Cannella, A. A., \& Dalton, D. R. 2003. Giving Money to Get Money: How CEO Stock Options and CEO Equity Enhance IPO Valuations. Academy of Management Journal, 46(5): 643-653. 
Chahine, S., Arthurs, J. D., Filatotchev, I., \& Hoskisson, R. E. 2012. The effects of venture capital syndicate diversity on earnings management and performance of IPOs in the US and UK: An institutional perspective. Journal of Corporate Finance, 18(1): 179192.

Chemmanur, T. J., Michel, J. S., Nandy, D. K., \& Yan, A. 2010. Capital structure and security issuance under heterogeneous beliefs, Working paper.

Claes, K., \& Vissa, B. 2017. Is Homophily Always Beneficial? Task-Relevant Homophily and VCs' Valuations and Returns. In Academy of Management Proceedings (Vol. 2017, No. 1, p. 16269). Briarcliff Manor, NY 10510: Academy of Management.

Cochrane, J. H. 2005. The risk and return of venture capital. Journal of Financial Economics, 75(1): 3-52.

Colombo, M. G., \& Shafi, K. 2016. Swimming with sharks in Europe: When are they dangerous and what can new ventures do to defend themselves? Strategic Management Journal: 37 (11): 2307-2322.

Connelly, B. L., Certo, S. T., Ireland, R. D., \& Reutzel, C. R. 2011. Signaling Theory: A Review and Assessment. Journal of Management, 37(1): 39-67.

Cooper, A. C., Woo, C. Y., \& Dunkelberg, W. C. 1988. Entrepreneurs' perceived chances for success. Journal of business venturing, 3(2): 97-108.

Cumming, D., \& Dai, N. 2010. Local bias in venture capital investments. Journal of Empirical Finance, 17(3): 362-380.

Cumming, D., \& Dai, N. 2013. Why do entrepreneurs switch lead venture capitalists? Entrepreneurship Theory and Practice. 37, 999-1017.

Cumming, D.J., \& Johan, S.A. 2013. Venture Capital and Private Equity Contracting: An International Perspective, 2nd Edition, Elsevier Science Academic Press.

Cyert, R. M. \& March, J. G. 1963. A Behavioral Theory of the Firm. Englewood Cliffs, NJ: Prentice Hall.

Da Rin, M., Hellmann, T., \& Puri, M. 2013. A survey of venture capital research. In Handbook of the Economics of Finance (Vol. 2, pp. 573-648). Elsevier.

Deutsch, Y., \& Ross, T. W. 2003. You are known by the directors you keep: Reputable directors as a signaling mechanism for young firms. Management Science, 49(8): 1003-1017.

Diestre, L., \& Rajagopalan, N. 2012. Are all sharks' dangerous? new biotechnology ventures and partner selection in R\&D alliances. Strategic Management Journal, 33(10): 1115-1134.

Dimov, D., Shepherd, D. A., \& Sutcliffe, K. M. 2007. Requisite expertise, firm reputation, and status in venture capital investment allocation decisions. Journal of Business Venturing, 22(4): 481502.

Dushnitsky, G. 2012. Corporate venture capital in the 21st century: an integral part of firms' innovation toolkit. In D. Cumming (Ed.), Oxford Handbook of Venture Capital. Oxford: Oxford University Press.

Dushnitsky, G., \& Shaver, J. M. 2009. Limitations to interorganizational knowledge acquisition: the paradox of corporate venture capital. Strategic Management Journal, 30(10): 1045-1064.

Ertug, G. \& Castellucci, F. 2013. Getting what you need: how reputation and status affect team performance, hiring, and salaries in the NBA. Academy of Management Journal, 56(2): 407431.

Ewens, M. \& Rhodes-Kropf, M. 2015. Is a VC Partnership Greater Than the Sum of Its Partners? The Journal of Finance, 70(3): 1081-1113.

Fischer, H. M., \& Pollock, T. G. 2004. Effects of social capital and power on surviving transformational change: The case of initial public offerings. Academy of Management Journal, 47(4): 463-481.

Fiske, S. T. \& Neuberg, S. L. 1990. A Continuum of Impression Formation, from Category-Based to Individuating Processes: Influences of Information and Motivation on Attention and Interpretation. In M. P. Zanna (Ed.), Advances in Experimental Social Psychology, Vol. 23: 1-74: Academic Press.

Fiske, S. T. \& Taylor, S. E. 1991. Social Cognition. New York: McGraw-Hill. 
Franke, N., Gruber, M., Harhoff, D., \& Henkel, J. 2008. Venture capitalists' evaluations of start-up teams: Trade-offs, knock-out criteria, and the impact of VC experience. Entrepreneurship Theory and Practice, 32(3): 459-483.

Fritz, M. S., \& MacKinnon, D. P. (2007). Required sample size to detect the mediated effect. Psychological Science, 18(3): 233-239.

Gaba, V. \& Meyer, A. D. 2008. Crossing the Organizational Species Barrier: How Venture Capital Practices Infiltrated the Information Technology Sector. Academy of Management Journal, 51(5): 976-998.

Garg, S. 2013. Venture boards: distinctive monitoring and implications for firm performance. Academy of Management Review, 38(1): 90-108.

Ge, D., Mahoney, J. M., \& Mahoney, J. T. 2005. New venture valuation by venture capitalists: An integrative approach. University of Illinois at Urban Champaign Working Paper, 124, 050124.

Gompers, P., \& Lerner, J. 1999. The venture capital cycle. Cambridge: MIT Press.

Gompers, P. A. 1995. Optimal investment, monitoring, and the staging of venture capital. The Journal of Finance, 50(5): 1461-1489.

Gompers, P. A. 1996. Grandstanding in the venture capital industry. Journal of Financial Economics, 42(1): 133-156.

Gompers, P. A., Ishii, J., \& Metrick, A. 2009. Extreme governance: An analysis of dual-class firms in the United States. The Review of Financial Studies, 23(3): 1051-1088.

Gorman, M., \& Sahlman, W. A. 1989. What do venture capitalists do. Journal of Business Venturing, 4(4): 231-248.

Gompers, P., Kovner, A., Lerner, J., \& Scharfstein, D. 2008. Venture capital investment cycles: The impact of public markets. Journal of Financial Economics, 87(1): 1-23.

Granovetter, M. 1985. Economic action and social structure: the problem of embeddedness. American Journal of Sociology, 91(3): 481-510.

Greve, H. R., Baum, J. A. C., Mitsuhashi, H., \& Rowley, T. J. 2010. Built to last but falling apart: cohesion, friction, and withdrawal from interfirm alliances. Academy of Management Journal, 53(2): 302-322.

Greve, H. R., Mitsuhashi, H., \& Baum, J. A. C. 2013. Greener pastures: outside options and strategic alliance withdrawal. Organization Science, 24(1): 79-98.

Gulati, R. 1995. Does Familiarity Breed Trust? The Implications of Repeated Ties for Contractual Choice in Alliances. The Academy of Management Journal, 38(1): 85-112.

Gulati, R. \& Gargiulo, M. 1999. Where do interorganizational networks come from? American Journal of Sociology, 104(5): 1439-1493.

Gulati, R., \& Higgins, M. C. 2003. Which ties matter when? The contingent effects of interorganizational partnerships on IPO success. Strategic Management Journal, 24(2): 127144.

Guler, I. 2007. Throwing good money after bad? Political and institutional influences on sequential decision making in the venture capital industry. Administrative Science Quarterly, 52(2): 248-285.

Hallen, B. L. 2008. The causes and consequences of the initial network positions of new organizations: From whom do entrepreneurs receive investments? Administrative Science Quarterly, 53(4): 685-718.

Hannan, M. T. \& Freeman, J. 1977. The Population Ecology of Organizations. American Journal of Sociology, 82(5): 929-964.

Heckman, J. J. 1979. Sample selection bias as a specification error. Econometrica, 47(1): 153-161.

Hellmann, T., \& Puri, M. 2000. The interaction between product market and financing strategy: The role of venture capital. The Review of Financial Studies, 13(4): 959-984.

Hellmann, T. \& Puri, M. 2002. Venture capital and the professionalization of start-up firms: Empirical evidence. Journal of Finance, 57(1): 169-197.

Higgins, M. C., \& Gulati, R. 2006. Stacking the deck: The effects of top management backgrounds on investor decisions. Strategic Management Journal, 27(1): 1-25.

Hochberg, Y. V., Ljungqvist, A., \& Lu, Y. 2007. Whom you know matters: Venture capital networks and investment performance. The Journal of Finance, 62(1): 251-301. 
Hsu, D. H. 2004. What do entrepreneurs pay for venture capital affiliation? The Journal of Finance, 59(4): 1805-1844.

Hsu, D. H. 2006. Venture capitalists and cooperative start-up commercialization strategy. Management Science, 52(2): 204-219.

Hsu, D. H., \& Ziedonis, R. H. 2013. Resources as dual sources of advantage: Implications for valuing entrepreneurial-firm patents. Strategic Management Journal, 34(7): 761-781.

Jain, B. A., \& Kini, O. 1995. Venture capitalist participation and the post-issue operating performance of IPO firms. Managerial and Decision Economics, 16(6): 593-606.

Jensen, M. \& Roy, A. 2008. Staging exchange partner choices: When do status and reputation matter? Academy of Management Journal, 51(3): 495-516.

Kale, P., \& Singh, H. 2009. Managing strategic alliances: what do we know now, and where do we go from here? Academy of Management Perspectives, 23(3): 45-62.

Kaplan, S. N., \& Stromberg, P. 2003. Financial contracting theory meets the real world: An empirical analysis of venture capital contracts. Review of Economic Studies, 70(2): 281-315.

Kaplan, S. N., \& Schoar, A. 2005. Private equity performance: Returns, persistence, and capital flows. The Journal of Finance, 60(4): 1791-1823.

Katila, R., Rosenberger, J. D., \& Eisenhardt, K. M. 2008. Swimming with sharks: Technology ventures, defense mechanisms and corporate relationships. Administrative Science Quarterly, 53(2): 295-332.

Koka, B. R., \& Prescott, J. E. 2008. Designing alliance networks: The influence of network position, environmental change, and strategy on firm performance. Strategic Management Journal, 29(6): 639-661.

Kortum, S. \& Lerner, J., 2001. Does venture capital spur innovation?. In Entrepreneurial inputs and outcomes: New studies of entrepreneurship in the United States, 1-44. Emerald Group Publishing Limited.

Lavie, D. 2006. The Competitive Advantage of Interconnected Firms: An Extension of the ResourceBased View. The Academy of Management Review, 31(3): 638-658.

Lee, P. M., Pollock, T. G., \& Jin, K. 2011. The contingent value of venture capitalist reputation. Strategic Organization, 9(1): 33-69.

Lee, P. M., \& Wahal, S. 2004. Grandstanding, certification and the underpricing of venture capital backed IPOs. Journal of Financial Economics, 73(2): 375-407.

Leland, H. E., \& Pyle, D. H. 1977. Informational asymmetries, financial structure, and financial intermediation. The Journal of Finance, 32(2): 371-387.

Lerner, J. 1994. The syndication of venture capital investments. Financial Management: 16-27.

Lerner, J. 1995. Venture capitalists and the oversight of private firms. The Journal of Finance, 50(1): 301-318.

Li, K., \& Prabhala, N. R. 2007. Self-selection models in corporate finance. In: Eckbo, B. Espen (Eds.), Handbook of Empirical Corporate Finance: 37-86. San Diego: Elsevier.

Li, Y. \& Chi, T. 2013. Venture capitalists' decision to withdraw: The role of portfolio configuration from a real options lens. Strategic Management Journal, 34(11): 1351-1366.

Lynn, F. B., Podolny, J. M., \& Tao, L. 2009. A Sociological (De)Construction of the Relationship between Status and Quality. American Journal of Sociology, 115(3): 755-804.

Maxwell, A. L., Jeffrey, S. A., \& Levesque, M. 2011. Business angel early stage decision making. Journal of Business Venturing, 26(2): 212-225.

Megginson, W. L., \& Weiss, K. A. 1991. Venture capitalist certification in initial public offerings. The Journal of Finance, 46(3): 879-903.

Milanov, H. \& Shepherd, D. A. 2013. The importance of the first relationship: The ongoing influence of initial network on future status. Strategic Management Journal, 34(6): 727-750.

Milgrom, P. \& Roberts, J. 1986. Price and Advertising Signals of Product Quality. Journal of Political Economy, 94(4): 796-821.

Mindruta, D., Moeen, M., \& Agarwal, R. 2016. A two-sided matching approach for partner selection and assessing complementarities in partners' attributes in inter-firm alliances. Strategic Management Journal, 37(1): 206-231.

Nanda, R. R.-K., M. 2017. Coordination Frictions in Venture Capital Syndicates, HBS Working Paper. 17-089. 
Ocasio, W. 1997. Towards an attention-based view of the firm. Strategic Management Journal, 18(S1): 187-206.

Ozmel, U., Reuer, J. J., \& Gulati, R. 2013. Signals across Multiple Networks: How Venture Capital and Alliance Networks Affect Interorganizational Collaboration. Academy of Management Journal, 56(3): 852-866.

Pahnke, E. C., Katila, R., \& Eisenhardt, K. M. 2015. Who takes you to the dance? How partners' institutional logics influence innovation in young firms. Administrative Science Quarterly, 60(4): 596-633.

Pahnke, E. C., McDonald, R., Wang, D., \& Hallen, B. 2015. Exposed: Venture Capital, Competitor Ties, and Entrepreneurial Innovation. Academy of Management Journal, 58(5): 1334-1360.

Peeters, G., \& Czapinski, J. 1990. Positive-negative asymmetry in evaluations: The distinction between affective and informational negativity effects. European Review of Social Psychology, 1(1), 33-60.

Pfarrer, M. D., Pollock, T. G., \& Rindova, V. P. 2010. A tale of two assets: the effects of firm reputation and celebrity on earnings surprises and investors' reactions. Academy of Management Journal, 53(5): 1131-1152.

Podolny, J. M. \& Philips, D. J. 1996. The Dynamics of Organizational Status. Industrial and Corporate Change, 5(2): 453-471.

Podolny, J. M. 1993. A status-based model of market competition. American Journal of Sociology, 98(4): 829-872.

Podolny, J. M. 1994. Market uncertainty and the social character of economic exchange. Administrative Science Quarterly, 39(3): 458-483.

Podolny, J. M. 2001. Networks as the pipes and prisms of the market. American Journal of Sociology, 107(1): 33-60.

Podolny, J. M., \& Philips, D. J. 1996. The dynamics of organizational status. Industrial and Corporate Change, 5(2): 453-471.

Polidoro Jr, F., Ahuja, G., \& Mitchell, W. 2011. When the social structure overshadows competitive incentives: The effects of network embeddedness on joint venture dissolution. Academy of Management Journal, 54(1): 203-223.

Pollock, T. G., \& Gulati, R. 2007. Standing out from the crowd: the visibility-enhancing effects of IPO-related signals on alliance formation by entrepreneurial firms. Strategic Organization, 5(4): 339-372.

Pollock, T. G., Lee, P. M., Jin, K., \& Lashley, K. 2015. (Un)Tangled: exploring the asymmetric coevolution of new venture capital firms' reputation and status. Administrative Science Quarterly, 60(3): 482-517.

Pollock, T. G., Chen, G. L., Jackson, E. M., \& Hambrick, D. C. 2010. How much prestige is enough? Assessing the value of multiple types of high-status affiliates for young firms. Journal of Business Venturing, 25(1): 6-23.

Preacher, K. J., \& Hayes, A. F. 2004. SPSS and SAS procedures for estimating indirect effects in simple mediation models. Behavior Research Methods, Instruments, \& Computers, 36(4): 717-731.

Puri, M., \& Zarutskie, R. 2012. On the life cycle dynamics of venture-capital- and non-venturecapital-financed firms. The Journal of Finance, 67(6): 2247-2293.

Ragozzino, R. \& Reuer, J. J. 2011. Geographic distance and corporate acquisitions: signals from IPO firms. Strategic Management Journal, 32(8): 876-894.

Raub, W., \& Weesie, J. 1990. Reputation and efficiency in social interactions - an example of network effects. American Journal of Sociology, 96(3): 626-654.

Reuer, J. J., Tong, T. W., \& Wu, C.-W. 2012. A Signaling Theory of Acquisition Premiums: Evidence from Ipo Targets. Academy of Management Journal, 55(3): 667-683.

Reuer, J. J. \& Lahiri, N. 2014. Searching for Alliance Partners: Effects of Geographic Distance on the Formation of R\&D Collaborations. Organization Science, 25(1): 283-298.

Rider, C. I. 2012. How Employees' Prior Affiliations Constrain Organizational Network Change. Administrative Science Quarterly, 57(3): 453-483.

Roberts, J. H. \& Lattin, J. M. 1997. Consideration: Review of Research and Prospects for Future Insights. Journal of Marketing Research, 34(3): 406-410. 
Rogan, M., \& Sorenson, O. 2014. Picking a (poor) partner: a relational perspective on acquisitions. Administrative Science Quarterly, 59(2): 301-329.

Rothaermel, F. T. \& Boeker, W. 2008. Old technology meets new technology: complementarities, similarities, and alliance formation. Strategic Management Journal, 29(1): 47-77.

Rowley, T. J., Greve, H. R., Rao, H., Baum, J. A., \& Shipilov, A. V. 2005. Time to break up: Social and instrumental antecedents of firm exits from exchange cliques. Academy of Management Journal, 48(3): 499-520

Rozin, P. \& Royzman, E. B. 2001. Negativity Bias, Negativity Dominance, and Contagion. Personality and Social Psychology Review, 5(4): 296-320.

Sahlman, W. A. 1990. The Structure and Governance of Venture-Capital Organizations. Journal of Financial Economics, 27(2): 473-521.

Sanders, W. G., \& Boivie, S. 2004. Sorting things out: Valuation of new firms in uncertain markets. Strategic Management Journal, 25(2): 167-186.

Sauder, M., Lynn, F., \& Podolny, J. M. 2012. Status: Insights from Organizational Sociology. In K. S. Cook \& D. S. Massey (Eds.), Annual Review of Sociology, Vol 38, Vol. 38: 267-283.

Schoonhoven, C. B., Eisenhardt, K. M., \& Lyman, K. 1990. Speeding products to market: Waiting time to first product introduction in new firms. Administrative Science Quarterly, 177-207.

Shane, S., \& Cable, D. 2002. Network ties, reputation, and the financing of new ventures. Management Science, 48(3): 364-381.

Shepherd, D. A., Zacharakis, A., \& Baron, R. A. 2003. VCs' decision processes: Evidence suggesting more experience may not always be better. Journal of Business Venturing, 18(3): 381-401.

Simon, H. A. 1979. Rational Decision Making in Business Organizations. The American Economic Review, 69(4): 493-513.

Sirri, E. R., \& Tufano, P. 1998. Costly search and mutual fund flows. The Journal of Finance, 53(5): 1589-1622.

Sorensen, M. 2007. How smart is smart money? A two-sided matching model of venture capital. The Journal of Finance, 62(6): 2725-2762.

Sorenson, O., \& Stuart, T. E. 2001. Syndication networks and the spatial distribution of venture capital investments. American Journal of Sociology, 106(6): 1546-1588.

Sorenson, O. \& Stuart, T. E. 2008. Bringing the Context Back In: Settings and the Search for Syndicate Partners in Venture Capital Investment Networks. Administrative Science Quarterly, 53(2): 266-294.

Spence, A. M. 1974. Market signaling: Informational transfer in hiring and related screening processes (Vol. 143). Harvard Univ Pr.

Stern, I., Dukerich, J. M., \& Zajac, E. 2014. Unmixed signals: How reputation and status affect alliance formation. Strategic Management Journal, 35(4): 512-531.

Stinchcombe, A. 1965. Social structure and organizations. The Handbook of Organizations, J.March, editor: 1425193.

Stock, J., \& Yogo, M. 2005. Testing for weak instruments in linear IV regression. In D. Andrews (Ed.), Identification and Inference for Econometric Models. New York: Cambridge University Press.

Stuart, T. E., Hoang, H., \& Hybels, R. C. 1999. Interorganizational endorsements and the performance of entrepreneurial ventures. Administrative Science Quarterly, 44(2): 315-349.

Sullivan, B. N., Haunschild, P., \& Page, K. 2007. Organizations non gratae? The impact of unethical corporate acts on interorganizational networks. Organization Science, 18(1): 55-70.

Townsend, R. R. 2015. Propagation of financial shocks: the case of venture capital. Management Science, 61(11): 2782-2802.

Tversky, A. \& Kahneman, D. 1974. Judgment under Uncertainty: Heuristics and Biases. Science, 185(4157): 1124-1131.

Tyebjee, T. T., \& Bruno, A. V. (1984). A model of venture capitalist investment activity. Management Science, 30(9): 1051-1066.

Washington, M., \& Zajac, E. J. 2005. Status evolution and competition: theory and evidence. Academy of Management Journal, 48(2): 282-296.

Wasserman, N. 2003. Founder-CEO succession and the paradox of entrepreneurial success. Organization Science, 14(2): 149-172. 
Wooldridge, J. M. 2010. Econometric analysis of cross section and panel data. MIT press.

Vella, F., \& Verbeek, M. 1999. Estimating and interpreting models with endogenous treatment effects. Journal of Business \& Economic Statistics, 17(4): 473-478.

Vissa, B. 2011. A Matching Theory of Entrepreneurs' Tie Formation Intentions and Initiation of Economic Exchange. Academy of Management Journal, 54(1): 137-158.

Zacharakis, A. L. \& Meyer, G. D. 1998. A lack of insight: Do venture capitalists really understand their own decision process? Journal of Business Venturing, 13(1): 57-76.

Zacharakis, A. L. \& Shepherd, D. A. 2001. The nature of information and overconfidence on venture capitalists' decision making. Journal of Business Venturing, 16(4): 311-332.

Zhelyazkov, P. I., \& Gulati, R. 2016. After the break-up: the relational and reputational consequences of withdrawals from venture capital syndicates. Academy of Management Journal, 59(1): 277-301. 
TABLES

Table 1- Descriptive Statistics and Correlation Matrix $(\mathrm{N}=535)$

\begin{tabular}{|c|c|c|c|c|c|c|c|c|c|c|c|c|c|c|}
\hline Variable & Mean & S.D. & (1) & (2) & (3) & (4) & (5) & (6) & (7) & (8) & (9) & (10) & (11) & (12) \\
\hline 1. Valuation ${ }^{\mathrm{a}}$ & 3.587 & 0.992 & --- & & & & & & & & & & & \\
\hline 2. Round Size ${ }^{a b}$ & 1.317 & 1.547 & 0.75 & --- & & & & & & & & & & \\
\hline 3. Outside round & 0.705 & 0.457 & 0.28 & 0.46 & --- & & & & & & & & & \\
\hline 4. VC centrality & 0.045 & 0.047 & 0.23 & 0.4 & 0.62 & --- & & & & & & & & \\
\hline 5.VC general experience ${ }^{a}$ & 3.048 & 2.328 & 0.27 & 0.49 & 0.85 & 0.87 & --- & & & & & & & \\
\hline 6. VC IPO experience ${ }^{a}$ & 1.362 & 1.279 & 0.29 & 0.46 & 0.69 & 0.92 & 0.89 & --- & & & & & & \\
\hline 7. VC withdrawal & 0.243 & 0.429 & 0.09 & 0.04 & 0.09 & 0.05 & 0.04 & 0.07 & --- & & & & & \\
\hline 8. Syndicate size & 3.477 & 2.034 & 0.4 & 0.58 & 0.47 & 0.49 & 0.53 & 0.51 & -0.01 & --- & & & & \\
\hline 9. Early stage & 0.308 & 0.462 & -0.26 & -0.18 & -0.16 & -0.1 & -0.14 & -0.13 & -0.09 & -0.15 & --- & & & \\
\hline 10. First round size & 1.525 & 1.164 & 0.59 & 0.41 & -0.01 & -0.09 & -0.06 & -0.06 & 0.13 & 0.26 & -0.23 & --- & & \\
\hline 11. California & 0.628 & 0.484 & 0.04 & 0.07 & 0.07 & 0.04 & 0.06 & 0.03 & -0.01 & -0.01 & -0.04 & -0.06 & --- & \\
\hline 12. IPO market size & 5.577 & 0.773 & 0.05 & -0.02 & 0.05 & 0.14 & 0.05 & 0.19 & 0.04 & 0.01 & 0.06 & -0.2 & 0.02 & --- \\
\hline 13. VC market size & 9.202 & 0.576 & 0.31 & 0.3 & 0.16 & 0.01 & 0.12 & 0.12 & -0.07 & 0.18 & -0.02 & 0.2 & -0.02 & -0.02 \\
\hline
\end{tabular}

a. This variable is logged

b. $\mathrm{N}=2181$. 
Table 2- Regression Results of Heckman Treatment Model

Table 2 provides the estimates for the effect of VC withdrawal on pre-money valuation of ventures (Model 1) and Round size (Model 2). Model 3 investigate the moderating effect of early stage (H2). Model 5 and 6 test the similar moderating effect using split sample analysis. Model 5 includes ventures that are in Early state while model 6 includes ventures that are in later stage. Lambda refers to the inverse mills ratio in the Heckman treatment effects models.

\begin{tabular}{|c|c|c|c|c|c|}
\hline Panel A: Main equation & $\begin{array}{c}\text { (1) } \\
\text { Valuation }^{a}\end{array}$ & $\begin{array}{c}(2) \\
\text { Round size }^{\mathrm{a}}\end{array}$ & $\begin{array}{c}\text { (3) } \\
\text { Valuation }^{\mathrm{a}}\end{array}$ & $\begin{array}{c}\quad(5) \\
\text { Valuation }^{\mathrm{a}}\end{array}$ & $\begin{array}{c}(4) \\
\text { Valuation }^{\mathrm{a}}\end{array}$ \\
\hline Sample: & & & & $\begin{array}{l}\text { Early stage } \\
\text { sample }\end{array}$ & $\begin{array}{l}\text { Late stage } \\
\text { sample }\end{array}$ \\
\hline VC withdrawal & $\begin{array}{l}-0.418^{* *} \\
(0.204)\end{array}$ & $\begin{array}{l}-0.956^{* * *} \\
(0.178)\end{array}$ & $\begin{array}{l}-0.242 \\
(0.182)\end{array}$ & $\begin{array}{l}-1.106^{* * *} \\
(0.372)\end{array}$ & $\begin{array}{l}-0.230 \\
(0.243)\end{array}$ \\
\hline Early stage & $\begin{array}{l}-0.214^{* * * *} \\
(0.069)\end{array}$ & $\begin{array}{c}0.015 \\
(0.050)\end{array}$ & $\begin{array}{l}-0.197^{* *} \\
(0.078)\end{array}$ & & \\
\hline VC withdrawal $\times$ Early stage & & & $\begin{array}{l}-0.287^{*} \\
(0.163)\end{array}$ & & \\
\hline Syndicate size & $\begin{array}{l}0.113^{* * *} \\
(0.016)\end{array}$ & $\begin{array}{l}0.339^{* * *} \\
(0.012)\end{array}$ & $\begin{array}{l}0.109^{* * *} \\
(0.017)\end{array}$ & $\begin{array}{l}0.150^{* * * *} \\
(0.031)\end{array}$ & $\begin{array}{l}0.105^{* * *} \\
(0.020)\end{array}$ \\
\hline First round size ${ }^{a}$ & $\begin{array}{l}0.449^{* * * *} \\
(0.032)\end{array}$ & $\begin{array}{l}0.424^{* * *} \\
(0.023)\end{array}$ & $\begin{array}{l}0.434^{* * *} \\
(0.032)\end{array}$ & $\begin{array}{l}0.343^{\text {*** }} \\
(0.058)\end{array}$ & $\begin{array}{l}0.483^{* * *} \\
(0.040)\end{array}$ \\
\hline California & $\begin{array}{l}0.194^{* * *} \\
(0.066)\end{array}$ & $\begin{array}{l}0.352^{* * *} \\
(0.051)\end{array}$ & $\begin{array}{c}0.154^{* *} \\
(0.066)\end{array}$ & $\begin{array}{c}0.044 \\
(0.114)\end{array}$ & $\begin{array}{l}0.265^{* * *} \\
(0.081)\end{array}$ \\
\hline IPO market size ${ }^{a}$ & $\begin{array}{l}-0.055 \\
(0.160)\end{array}$ & $\begin{array}{l}-0.085 \\
(0.093)\end{array}$ & $\begin{array}{l}0.206^{* * *} \\
(0.042)\end{array}$ & $\begin{array}{c}0.354 \\
(0.286)\end{array}$ & $\begin{array}{l}-0.134 \\
(0.188)\end{array}$ \\
\hline VC market size ${ }^{a}$ & $\begin{array}{l}-0.115 \\
(0.547)\end{array}$ & $\begin{array}{c}0.234 \\
(0.287)\end{array}$ & $\begin{array}{l}0.253^{* * *} \\
(0.059)\end{array}$ & $\begin{array}{l}-0.823 \\
(0.849)\end{array}$ & $\begin{array}{l}-0.129 \\
(0.646)\end{array}$ \\
\hline $\begin{array}{l}\text { Year fixed-effect } \\
\text { Industry fixed-effect }\end{array}$ & $\begin{array}{l}\text { YES } \\
\text { YES }\end{array}$ & $\begin{array}{l}\text { YES } \\
\text { YES }\end{array}$ & $\begin{array}{l}\text { YES } \\
\text { YES }\end{array}$ & $\begin{array}{l}\text { YES } \\
\text { YES }\end{array}$ & $\begin{array}{l}\text { YES } \\
\text { YES }\end{array}$ \\
\hline Lambda & $\begin{array}{l}0.290^{* *} \\
(0.126)\end{array}$ & $\begin{array}{c}0.535^{* * *} \\
(0.107)\end{array}$ & $\begin{array}{l}0.342^{* *} \\
(0.159)\end{array}$ & $\begin{array}{c}0.579^{* * *} \\
(0.219)\end{array}$ & $\begin{array}{c}0.218 \\
(0.153)\end{array}$ \\
\hline $\mathrm{N}$ & 535 & 2181 & 535 & 165 & 370 \\
\hline Wald chi-squared & $558.715^{* * *}$ & $2229.462^{* * *}$ & $493.758^{* * *}$ & $132.889^{* * *}$ & $411.552^{* * *}$ \\
\hline
\end{tabular}

Note: $* p<0.10, * * p<0.05, * * * p<0.01$

a. This variable is logged. 
Table 2- Continued

\begin{tabular}{|c|c|c|c|c|c|}
\hline \multicolumn{6}{|c|}{ Panel B: Treatment equation (DV: VC withdrawal) } \\
\hline Other state deal growth & $\begin{array}{c}0.058^{*} \\
(0.035)\end{array}$ & $\begin{array}{c}0.021^{*} \\
(0.012)\end{array}$ & $\begin{array}{c}0.058^{*} \\
(0.035)\end{array}$ & $\begin{array}{c}0.027 \\
(0.090)\end{array}$ & $\begin{array}{c}0.037 \\
(0.041)\end{array}$ \\
\hline Distance $^{a}$ & $\begin{array}{l}0.119^{* *} \\
(0.051)\end{array}$ & $\begin{array}{l}0.082^{* * * *} \\
(0.023)\end{array}$ & $\begin{array}{l}0.119^{* *} \\
(0.051)\end{array}$ & $\begin{array}{c}0.250^{*} \\
(0.131)\end{array}$ & $\begin{array}{c}0.100^{*} \\
(0.058)\end{array}$ \\
\hline Syndication diversity & $\begin{array}{l}0.824^{\text {**** }} \\
(0.131)\end{array}$ & $\begin{array}{l}0.704^{* * *} \\
(0.062)\end{array}$ & $\begin{array}{l}0.824^{* * * *} \\
(0.131)\end{array}$ & $\begin{array}{l}1.045^{\text {**** }} \\
(0.315)\end{array}$ & $\begin{array}{l}0.775^{\text {*** }} \\
(0.146)\end{array}$ \\
\hline First round size ${ }^{a}$ & $\begin{array}{c}0.073 \\
(0.061)\end{array}$ & $\begin{array}{l}0.119^{* * *} \\
(0.028)\end{array}$ & $\begin{array}{c}0.073 \\
(0.061)\end{array}$ & $\begin{array}{l}-0.081 \\
(0.132)\end{array}$ & $\begin{array}{c}0.105 \\
(0.073)\end{array}$ \\
\hline Early and seed stage & $\begin{array}{l}-0.039 \\
(0.136)\end{array}$ & $\begin{array}{c}0.032 \\
(0.066)\end{array}$ & $\begin{array}{l}-0.039 \\
(0.136)\end{array}$ & $\begin{array}{l}-0.051 \\
(0.270)\end{array}$ & $\begin{array}{c}0.174 \\
(0.162)\end{array}$ \\
\hline California & $\begin{array}{c}0.108 \\
(0.135)\end{array}$ & $\begin{array}{l}-0.022 \\
(0.065)\end{array}$ & $\begin{array}{c}0.108 \\
(0.135)\end{array}$ & & \\
\hline IPO market size ${ }^{a}$ & $\begin{array}{c}0.326^{* *} \\
(0.127)\end{array}$ & $\begin{array}{l}0.238^{* * *} \\
(0.055)\end{array}$ & $\begin{array}{l}0.326^{* *} \\
(0.127)\end{array}$ & $\begin{array}{c}0.055 \\
(0.275)\end{array}$ & $\begin{array}{c}0.358^{* *} \\
(0.152)\end{array}$ \\
\hline VC market size ${ }^{a}$ & $\begin{array}{l}-0.015 \\
(0.131)\end{array}$ & $\begin{array}{l}-0.005 \\
(0.059)\end{array}$ & $\begin{array}{l}-0.015 \\
(0.131)\end{array}$ & $\begin{array}{l}-0.381 \\
(0.326)\end{array}$ & $\begin{array}{c}0.014 \\
(0.147)\end{array}$ \\
\hline Crisis & YES & YES & YES & YES & YES \\
\hline Bubble & YES & YES & YES & YES & YES \\
\hline Industry fixed effect & YES & YES & YES & YES & YES \\
\hline $\mathrm{N}$ & 535 & 2181 & 535 & 165 & 370 \\
\hline
\end{tabular}

Note: $* \mathrm{p}<0.10, * * \mathrm{p}<0.05, * * * \mathrm{p}<0.01$

a. This variable is logged. 
Table 3- Regression Results of Mediation Effect Using Heckman Treatment Model $(\mathbf{N}=535)$

Table 3 provides the estimates for the mediation effect of outside round, VC status (VC centrality), and VC reputation (VC general experience, and VC IPO experience). All regressions include: Early stage, Syndicate size, first round size, California, IPO market size, VC market size, Year, and industry fixed effect.

\begin{tabular}{|c|c|c|c|c|c|c|c|c|c|}
\hline & (1) & (2) & (3) & (4) & (5) & $(6)$ & (7) & (8) & (9) \\
\hline & \multicolumn{4}{|c|}{ Mediators } & \multicolumn{5}{|c|}{ Valuation $^{a}$} \\
\hline & $\begin{array}{c}\text { Outside } \\
\text { round }\end{array}$ & $\begin{array}{c}\mathrm{VC} \\
\text { centrality }\end{array}$ & $\begin{array}{l}\text { VC general } \\
\text { experience }^{\mathrm{a}}\end{array}$ & $\begin{array}{c}\text { VC IPO } \\
\text { experience }^{\mathrm{a}}\end{array}$ & & & & & \\
\hline VC withdrawal & $\begin{array}{l}-0.230^{* *} \\
(0.114)\end{array}$ & $\begin{array}{l}-0.024^{* *} \\
(0.011)\end{array}$ & $\begin{array}{l}-1.343^{* *} \\
(0.555)\end{array}$ & $\begin{array}{l}-0.684^{* *} \\
(0.298)\end{array}$ & $\begin{array}{l}-0.418^{* *} \\
(0.204)\end{array}$ & $\begin{array}{l}-0.373^{*} \\
(0.200)\end{array}$ & $\begin{array}{l}-0.327^{*} \\
(0.198)\end{array}$ & $\begin{array}{l}-0.321^{*} \\
(0.195)\end{array}$ & $\begin{array}{l}-0.313^{*} \\
(0.195)\end{array}$ \\
\hline Outside round & & & & & & $\begin{array}{l}0.294^{\text {*** }} \\
(0.079)\end{array}$ & & & \\
\hline VC centrality & & & & & & & $\begin{array}{l}3.756^{* * * *} \\
(0.781)\end{array}$ & & \\
\hline VC general experience ${ }^{a}$ & & & & & & & & $\begin{array}{l}0.073^{* * *} \\
(0.016)\end{array}$ & \\
\hline VC IPO experience ${ }^{a}$ & & & & & & & & & $\begin{array}{l}0.154^{* * * *} \\
(0.030)\end{array}$ \\
\hline Controls & YES & YES & YES & YES & YES & YES & YES & YES & YES \\
\hline Lambda & $\begin{array}{c}0.266^{* * * *} \\
(0.069)\end{array}$ & $\begin{array}{c}0.020^{* * * *} \\
(0.007)\end{array}$ & $\begin{array}{l}1.139^{* * *} \\
(0.341)\end{array}$ & $\begin{array}{c}0.586^{* * *} \\
(0.183)\end{array}$ & $\begin{array}{l}0.290^{* *} \\
(0.126)\end{array}$ & $\begin{array}{c}0.237^{*} \\
(0.125)\end{array}$ & $\begin{array}{c}0.215^{*} \\
(0.123)\end{array}$ & $\begin{array}{c}0.207^{*} \\
(0.124)\end{array}$ & $\begin{array}{c}0.200 \\
(0.123)\end{array}$ \\
\hline Wald chi-squared & $357.342^{* * *}$ & $311.747^{* * *}$ & $366.669^{* * *}$ & $392.779^{* * *}$ & $558.715^{* * *}$ & $599.026^{* * *}$ & $622.862^{* * *}$ & $618.244^{* * *}$ & $632.968^{* * *}$ \\
\hline
\end{tabular}

Note: $* p<0.10, * * p<0.05, * * * p<0.01$.

a. This variable is logged. 


\section{SUPPLEMENTARY APPENDIX}

\section{Appendix 1- 2SLS Specification}

This table provides the 2SLS estimates for the effect of VC withdrawal on Valuation (Model 1) and Round size (Model 2). Estimates of first stage are presented in Model 3 and Model 4.

\begin{tabular}{|c|c|c|c|c|}
\hline & \multicolumn{2}{|c|}{ Second stage } & \multicolumn{2}{|c|}{ First Stage } \\
\hline & $\begin{array}{c}\text { (1) } \\
\text { Valuation }\end{array}$ & $\begin{array}{c}(2) \\
\text { Valuation } \\
\text { a }\end{array}$ & $\begin{array}{c}(3) \\
\text { VC withdrawal }\end{array}$ & $\begin{array}{c}\text { (4) } \\
\text { VC withdrawal }\end{array}$ \\
\hline VC withdrawal & $\begin{array}{l}-0.395^{* *} \\
(0.195)\end{array}$ & $\begin{array}{l}-0.868^{* * *} \\
(0.176)\end{array}$ & & \\
\hline Early stage & $\begin{array}{l}-0.235^{* * *} \\
(0.072)\end{array}$ & $\begin{array}{l}-0.022 \\
(0.053)\end{array}$ & $\begin{array}{l}-0.045 \\
(0.040)\end{array}$ & $\begin{array}{l}-0.043^{* *} \\
(0.018)\end{array}$ \\
\hline Syndicate size & $\begin{array}{l}0.099^{* * *} \\
(0.017)\end{array}$ & $\begin{array}{l}0.313^{* * *} \\
(0.013)\end{array}$ & $\begin{array}{l}-0.029^{* * *} \\
(0.009)\end{array}$ & $\begin{array}{l}-0.029^{* * *} \\
(0.004)\end{array}$ \\
\hline First round size ${ }^{a}$ & $\begin{array}{l}0.453^{* * *} \\
(0.032)\end{array}$ & $\begin{array}{l}0.426^{\text {**** }} \\
(0.024)\end{array}$ & $\begin{array}{c}0.028 \\
(0.017)\end{array}$ & $\begin{array}{l}0.038^{* * *} \\
(0.007)\end{array}$ \\
\hline California & $\begin{array}{l}0.199^{* * *} \\
(0.066)\end{array}$ & $\begin{array}{l}0.361^{* * *} \\
(0.050)\end{array}$ & $\begin{array}{c}0.041 \\
(0.037)\end{array}$ & $\begin{array}{c}0.003 \\
(0.017)\end{array}$ \\
\hline IPO market size ${ }^{a}$ & $\begin{array}{c}0.011 \\
(0.166)\end{array}$ & $\begin{array}{l}-0.101 \\
(0.096)\end{array}$ & $\begin{array}{l}-0.067 \\
(0.054)\end{array}$ & $\begin{array}{c}0.008 \\
(0.034)\end{array}$ \\
\hline VC market size ${ }^{a}$ & $\begin{array}{l}-0.284 \\
(0.577)\end{array}$ & $\begin{array}{c}0.255 \\
(0.298)\end{array}$ & $\begin{array}{c}0.180^{* * *} \\
(0.091)\end{array}$ & $\begin{array}{c}0.032 \\
(0.059)\end{array}$ \\
\hline Other state deal growth & & & $\begin{array}{c}0.019^{*} \\
(0.010)\end{array}$ & $\begin{array}{c}0.007^{* *} \\
(0.003)\end{array}$ \\
\hline Distance & & & $\begin{array}{r}0.023^{*} \\
(0.012)\end{array}$ & $\begin{array}{l}0.017^{* * *} \\
(0.005)\end{array}$ \\
\hline Syndication diversity & & & $\begin{array}{l}0.302^{* * *} \\
(0.038)\end{array}$ & $\begin{array}{l}0.256^{* * *} \\
(0.018)\end{array}$ \\
\hline Constant & $\begin{array}{c}5.126 \\
(4.662)\end{array}$ & $\begin{array}{l}-1.811 \\
(2.400)\end{array}$ & $\begin{array}{l}-1.952^{* *} \\
(0.767)\end{array}$ & $\begin{array}{l}-0.500 \\
(0.436)\end{array}$ \\
\hline $\begin{array}{l}\text { Year fixed effect } \\
\text { Industry fixed effect }\end{array}$ & $\begin{array}{l}\text { YES } \\
\text { YES }\end{array}$ & $\begin{array}{l}\text { YES } \\
\text { YES }\end{array}$ & $\begin{array}{l}\text { YES } \\
\text { YES }\end{array}$ & $\begin{array}{l}\text { YES } \\
\text { YES }\end{array}$ \\
\hline $\begin{array}{l}\mathrm{N} \\
\mathrm{chi} 2\end{array}$ & $\begin{array}{c}535 \\
553.773^{* * *}\end{array}$ & $\begin{array}{c}2181 \\
2163.689^{* * * *}\end{array}$ & 535 & 2181 \\
\hline $\begin{array}{l}\text { F-statistic } \\
\text { R-square }\end{array}$ & 0.4924 & 0.4767 & $\begin{array}{c}28.043^{* * *} \\
0.2098\end{array}$ & $\begin{array}{c}90.333^{* * *} \\
0.1762\end{array}$ \\
\hline
\end{tabular}

Note: $* p<0.10, * * p<0.05, * * * p<0.01$

a. This variable is logged. 
Appendix 2- Regression Results of Mediation Effect Using Heckman Treatment Model (N=2181)

Table 3 provides the estimates for the mediation effect of outside round, VC status (VC centrality), and VC reputation (VC general experience, and VC IPO experience). All regressions include: Early stage, Syndicate size, first round size, California, IPO market size, VC market size, Year, and industry fixed effect.

\begin{tabular}{|c|c|c|c|c|c|c|c|c|c|}
\hline & (1) & (2) & (3) & \multirow[t]{2}{*}{ (4) } & (5) & (6) & (7) & (8) & (9) \\
\hline & \multicolumn{3}{|c|}{ Mediators } & & \multicolumn{5}{|c|}{ Round size $\mathrm{s}^{\mathrm{a}}$} \\
\hline & $\begin{array}{l}\text { Outside } \\
\text { round }\end{array}$ & $\begin{array}{c}\mathrm{VC} \\
\text { centrality }\end{array}$ & $\begin{array}{l}\text { VC general } \\
\text { experience }^{\mathrm{a}}\end{array}$ & $\begin{array}{c}\text { VC IPO } \\
\text { experience }^{\mathrm{a}}\end{array}$ & & & & & \\
\hline VC withdrawal & $\begin{array}{l}-0.390^{* * * *} \\
(0.074)\end{array}$ & $\begin{array}{l}-0.030^{* * * *} \\
(0.006)\end{array}$ & $\begin{array}{l}-1.069^{* * *} \\
(0.168)\end{array}$ & $\begin{array}{l}-2.188^{* * *} \\
(0.339)\end{array}$ & $\begin{array}{l}-0.956^{* * *} \\
(0.178)\end{array}$ & $\begin{array}{l}-0.601^{* * *} \\
(0.162)\end{array}$ & $\begin{array}{l}-0.713^{* * *} \\
(0.169)\end{array}$ & $\begin{array}{l}-0.520^{* * * *} \\
(0.163)\end{array}$ & $\begin{array}{l}-0.597^{* * * *} \\
(0.167)\end{array}$ \\
\hline Outside round & & & & & & $\begin{array}{l}0.909^{* * *} \\
(0.052)\end{array}$ & & & \\
\hline VC centrality & & & & & & & $\begin{array}{l}8.015^{* * *} \\
(0.660)\end{array}$ & & \\
\hline VC general experience ${ }^{a}$ & & & & & & & & $\begin{array}{l}0.199^{* * *} \\
(0.012)\end{array}$ & \\
\hline VC IPO experience ${ }^{a}$ & & & & & & & & & $\begin{array}{l}0.336^{* * *} \\
(0.024)\end{array}$ \\
\hline Controls & YES & YES & YES & YES & YES & YES & YES & YES & YES \\
\hline Lambda & $\begin{array}{l}0.355^{* * * *} \\
(0.044)\end{array}$ & $\begin{array}{c}0.023^{* * * *} \\
(0.003)\end{array}$ & $\begin{array}{c}0.838^{* * *} \\
(0.100)\end{array}$ & $\begin{array}{l}1.738^{* * *} \\
(0.201)\end{array}$ & $\begin{array}{c}0.535^{* * *} \\
(0.107)\end{array}$ & $\begin{array}{l}0.212^{* *} \\
(0.099)\end{array}$ & $\begin{array}{l}0.349^{* * *} \\
(0.103)\end{array}$ & $\begin{array}{l}0.188^{*} \\
(0.100)\end{array}$ & $\begin{array}{l}0.253^{* * *} \\
(0.102)\end{array}$ \\
\hline
\end{tabular}

Note: $* p<0.10, * * p<0.05, * * * p<0.01$

a. This variable is logged. 


\section{Appendix 3- Regression Results of Heckman Treatment Effects - Sample Obtained from Propensity Score Matching}

Appendix 3 provides the estimates for the effect of $\mathrm{VC}$ withdrawal on Valuation, Round size with a sample obtained from propensity score matching. All regressions include: Early stage, Syndicate size, first round size, California, IPO market size, VC market size.

\begin{tabular}{lcc}
\hline & $\begin{array}{c}(\mathbf{1}) \\
\text { Valuation }^{\mathrm{a}}\end{array}$ & $\begin{array}{c}(\mathbf{2}) \\
\text { Round size }^{\mathrm{a}}\end{array}$ \\
\hline VC withdrawal & -0.203 & $-0.617^{* * *}$ \\
& $(0.239)$ & $(0.215)$ \\
Controls & YES & YES \\
Year FE & YES & YES \\
Industry FE & YES & YES \\
\hline Lambda & $0.237^{*}$ & $0.346^{* *}$ \\
\multicolumn{1}{c}{$(0.161)$} & $(0.141)$ \\
Wald chi-squared & $253.967^{* * *}$ & $877.3096^{* * *}$ \\
\hline Note: $* p<0.10, p<0.05, * * *<<0.01$ \\
\multicolumn{2}{c}{ a. This variable is logged. }
\end{tabular}

\section{Appendix 4- Difference-in-Difference Estimation}

Model 2(1) does (not) include venture fixed effects. The sample include only non-IT firms. Due to very small sample we are not able to repeat the same analysis for valuation. All regressions include: Early stage, Syndicate size, first round size, California, IPO market size, VC market size. California is dropped from Model 2 due to inclusion of fixed effect.

\begin{tabular}{lcc}
\hline & \multicolumn{2}{c}{ Round size $^{\mathrm{a}}$} \\
\cline { 2 - 3 } & $(\mathbf{1})$ & $(\mathbf{2})$ \\
\hline IT exposure & 0.082 & \\
\multirow{2}{*}{ Post } & $(0.286)$ & \\
& $0.481^{*}$ & 0.104 \\
Post $\times$ IT exposure & $(0.262)$ & $(0.279)$ \\
& $\mathbf{- 0 . 7 2 9 *}^{* *}$ & $\mathbf{- 0 . 6 8 4 ^ { * * }}$ \\
Controls & $\mathbf{( 0 . 3 3 7 )}^{\text {YES }}$ & $\mathbf{( 0 . 3 1 8 )}$ \\
\hline Venture Fixed effect & NES \\
\hline N & 340 & YES \\
No of Firms & 170 & 340 \\
\hline Note: $* p<0.10, * * p<0.05, * * *<0.01$
\end{tabular}

a. This variable is logged. 
Appendix 5- Regression Results of Successful Exit and Hazard of Success Using

Heckman Treatment Model and Cox Model

This table provides the estimates for the effect of VC withdrawal on Successful exit and Hazard of time. Successful exit is defined as IPO or trade sale. Model 1 and 2 are based on the sample with nonmissing Valuation data $(\mathrm{N}=535)$, while Model 3 and 4 are based on the sample with non-missing Round size data $(\mathrm{N}=2181)$.
(1)
(2)
(3)
(4)

Successful exit Hazard of success Successful exit Hazard of success

\begin{tabular}{|c|c|c|c|c|}
\hline VC withdrawal & $\begin{array}{c}0.203 \\
(0.132)\end{array}$ & $\begin{array}{l}-0.021 \\
(0.140)\end{array}$ & $\begin{array}{l}-0.036 \\
(0.074)\end{array}$ & $\begin{array}{c}0.050 \\
(0.073)\end{array}$ \\
\hline Early stage & $\begin{array}{l}-0.001 \\
(0.045)\end{array}$ & $\begin{array}{l}-0.068 \\
(0.134)\end{array}$ & $\begin{array}{l}-0.017 \\
(0.022)\end{array}$ & $\begin{array}{l}-0.077 \\
(0.067)\end{array}$ \\
\hline Syndicate size & $\begin{array}{c}0.006 \\
(0.011)\end{array}$ & $\begin{array}{l}-0.014 \\
(0.031)\end{array}$ & $\begin{array}{l}0.026^{* * *} \\
(0.005)\end{array}$ & $\begin{array}{l}0.052^{* * * *} \\
(0.014)\end{array}$ \\
\hline First round size ${ }^{a}$ & $\begin{array}{c}0.020 \\
(0.021)\end{array}$ & $\begin{array}{c}0.119^{* *} \\
(0.060)\end{array}$ & $\begin{array}{l}0.030^{* * *} \\
(0.010)\end{array}$ & $\begin{array}{l}0.079^{* * *} \\
(0.028)\end{array}$ \\
\hline California & $\begin{array}{l}-0.061 \\
(0.043)\end{array}$ & $\begin{array}{l}-0.119 \\
(0.122)\end{array}$ & $\begin{array}{l}-0.010 \\
(0.021)\end{array}$ & $\begin{array}{l}-0.015 \\
(0.062)\end{array}$ \\
\hline IPO market size ${ }^{a}$ & $\begin{array}{l}-0.042 \\
(0.106)\end{array}$ & $\begin{array}{l}-0.012 \\
(0.453)\end{array}$ & $\begin{array}{l}-0.034 \\
(0.040)\end{array}$ & $\begin{array}{l}-0.076 \\
(0.164)\end{array}$ \\
\hline VC market size ${ }^{a}$ & $\begin{array}{c}0.190 \\
(0.363)\end{array}$ & $\begin{array}{l}-0.086 \\
(1.606)\end{array}$ & $\begin{array}{l}0.105 \\
(0.125)\end{array}$ & $\begin{array}{c}0.318 \\
(0.539)\end{array}$ \\
\hline $\begin{array}{l}\text { Year fixed-effect } \\
\text { Industry fixed-effect }\end{array}$ & $\begin{array}{l}\text { YES } \\
\text { YES }\end{array}$ & $\begin{array}{l}\text { YES } \\
\text { YES }\end{array}$ & $\begin{array}{l}\text { YES } \\
\text { YES }\end{array}$ & $\begin{array}{l}\text { YES } \\
\text { YES }\end{array}$ \\
\hline Lambda & $\begin{array}{l}-0.125 \\
(0.082) \\
\end{array}$ & & $\begin{array}{c}0.031 \\
(0.045) \\
\end{array}$ & \\
\hline $\mathrm{N}$ & 535 & 535 & 2181 & 2181 \\
\hline Model & Heckman & Cox & Heckman & Cox \\
\hline Wald chi-squared & $108.886^{* * *}$ & $81.146^{* * *}$ & $328.239^{* * *}$ & $232.577^{* * *}$ \\
\hline
\end{tabular}

Note: $* p<0.10, * * p<0.05, * * * p<0.01$

a. This variable is logged. 